IZA DP No. 4956

High Performance Work Practices and Employee Voice: A Comparison of Japanese and Korean Workers

Kiu-Sik Bae

Hiroyuki Chuma

Takao Kato

May 2010
Dong-Bae Kim

Isao Ohashi 


\title{
High Performance Work Practices and Employee Voice: A Comparison of Japanese and Korean Workers
}

\author{
Kiu-Sik Bae
}

Korea Labor Institute

Hiroyuki Chuma

Hitotsubashi University

Takao Kato

Colgate University, CJEB (Columbia), TCER (Tokyo), CCP (Aarhus) and IZA

Dong-Bae Kim

University of Incheon

Isao Ohashi

Hitotsubashi University

Discussion Paper No. 4956

May 2010

IZA

P.O. Box 7240

53072 Bonn

Germany

Phone: +49-228-3894-0

Fax: +49-228-3894-180

E-mail: iza@iza.org

\begin{abstract}
Any opinions expressed here are those of the author(s) and not those of IZA. Research published in this series may include views on policy, but the institute itself takes no institutional policy positions.

The Institute for the Study of Labor (IZA) in Bonn is a local and virtual international research center and a place of communication between science, politics and business. IZA is an independent nonprofit organization supported by Deutsche Post Foundation. The center is associated with the University of Bonn and offers a stimulating research environment through its international network, workshops and conferences, data service, project support, research visits and doctoral program. IZA engages in (i) original and internationally competitive research in all fields of labor economics, (ii) development of policy concepts, and (iii) dissemination of research results and concepts to the interested public.
\end{abstract}

IZA Discussion Papers often represent preliminary work and are circulated to encourage discussion. Citation of such a paper should account for its provisional character. A revised version may be available directly from the author. 


\title{
ABSTRACT \\ High Performance Work Practices and Employee Voice: A Comparison of Japanese and Korean Workers
}

\begin{abstract}
Using a unique new cross-national survey of Japanese and Korean workers, we report the first systematic evidence on the effects on employee voice of High Performance Work Practices (HPWPs) from the two economies which are noted for the wide use of HPWPs. We find for both nations that: (i) workers in firms with HPWPs aimed at creating opportunities for employees to get involved (such as shopfloor committees and small group activities) are indeed more likely to have stronger senses of influence and voice on shopfloor decision making than other workers; (ii) workers whose pay is tied to firm performance are more likely to have a stake in firm performance and hence demand such influence and voice; and (iii) consequently workers in firms with HPWPs are more likely to make frequent suggestions for productivity increase and quality improvement. As such, this paper contributes to a small yet growing new empirical literature which tries to understand the actual process and mechanism through which HPWPs lead to better enterprise performance.
\end{abstract}

JEL Classification: J53, M54, M52

Keywords: $\quad$ high performance work practices, employee voice, Japan, Korea

Corresponding author:

Takao Kato

Department of Economics

Colgate University

13 Oak Drive

Hamilton, NY 13346

USA

E-mail: tkato@colgate.edu

\footnotetext{
* The Japanese Worker Representation and Participation Survey was made possible by generous support from the RIETI (Research Institute of Economy, Trade and Industry); the Abe Fellowship Program of the Social Sciences Research Council and the American Council of Learned Societies with funds provided by the Japan Foundation Center for Global Partnership; the Nihon Keizai Kenkyu Shorei Zaidan; and Denki Rengo (Japanese Electrical, Electronic, Information Union). The Korean Worker Representation and Participation Survey was made possible by generous support from the KLI (Korea Labor Institute) and Metal Union. We are also thankful to Richard Freeman for his continued encouragement and advice. The paper also benefited from comments and suggestions from Hideo Owan (discussant) and participants at the ASSA Meetings, San Francisco, January 3, 2009; Jesse Shapiro (discussant) and participants at the NBER Japan Project Meeting, Tokyo, June 25, 2008; participants at the Trans-Pacific Labor Seminar, UC Santa Barbara, March 10-11, 2007 as well as at the seminar series at the Helsinki School of Economics, March 2006. The views in this paper are solely the responsibility of the authors.
} 


\section{High Performance Work Practices and Employee Voice: A Comparison of Japanese and Korean Workers}

\section{Introduction}

One of the most important changes in workplaces in Japan, the U.S., and other industrialized countries in the last two decades or so is the emergence of a new work system often called the High Performance Work System. ${ }^{1}$ In stark contrast to the traditional employment system, the High Performance Work System is based on a fundamentally different premise that frontline workers can play a significant role in enhancing the firm's overall competitiveness in the market. ${ }^{2}$ First, frontline workers acquire a variety of local knowledge through their frequent interactions with their equipments in the case of manufacturing sector and their customers in the case of service sector. Some of such local knowledge may prove to be a significant source of competitive edge for the firm (e.g., implementing a series of small yet useful ideas to improve productivity, quality, and customer satisfaction and reduce costs may eventually help the firm out-compete its rivals). In addition, the accumulation of such local knowledge tends to be most effective when frontline workers collaborate with each other and engage in knowledge sharing.

Second, the firm encounters a variety of shocks. Some of such shocks are local in nature and dealt with most effectively by frontline workers themselves without involving formal and inevitably time-consuming interventions from higher-level management and engineers. Such

\footnotetext{
${ }^{1}$ Calling the new work system the "high performance" work system might give some readers an impression that there is overwhelmingly strong evidence for the significant performance-enhancing effect of such a system. As discussed below, researchers are still debating the reliability of such evidence and new evidence is still being reported. We use the term "high performance" only because it is rather well established in the literature.

${ }^{2}$ We define frontline workers broadly, including all workers who are working in trenches, regularly interacting with machines in the case of manufacturing and customers in the case of service (such as machine operators, customer service representatives, sales professionals, and lower-level engineers and managers).
} 
local adjustments to shocks by frontline workers are often most successful when they collaborate with each other. ${ }^{3}$

In short, the High Performance Work System uses a variety of complementary new work practices (often called High Performance Work Practices, HPWPs) and taps into the ability of frontline workers to produce valuable local knowledge through their collective efforts and share it with management; and deal with local shocks autonomously through collaboration among themselves. Such diverse HPWPs can be grouped into the following three key elements of the High Performance Work System. ${ }^{4}$

Opportunities: First, in the High Performance Work System, front-line workers will be given opportunities to exert discretionary effort, acquire useful local knowledge, and share it with their co-workers, and higher-level engineers and managers. Various types of teams are used to create such opportunities for front-line workers as well as to deal with local shocks autonomously. The importance of providing such opportunities is self-explanatory. After all, a key objective of the High Performance Work System is to tap into frontline workers' discretional effort and ability to produce valuable local information and deal with local shocks. Without such opportunities, there will not be any performance gain.

Incentives: Providing workers with such opportunities to produce useful local knowledge and share it with management is not sufficient. Obviously if the interest of workers is not aligned with that of the firm, workers will have little incentive to put force effort and produce performance-enhancing local information and share it with management. The interest alignment between workers and the firm is fostered by two types of human resource management policies: (i) financial participation schemes (such as employee stock ownership, profit sharing,

\footnotetext{
${ }^{3}$ See, for instance, Koike (2005).

${ }^{4}$ See, for instance, Kochan and Osterman, 1994, Appelbaum, et. al. 2000 and Boning, Ichniowski and Shaw, 2007.
} 
gainsharing, and broad-based stock option) by which the financial wellbeing of workers is more tied to the final wellbeing of the firm; and (ii) information sharing mechanisms through which management shares important information with workers, and fosters their loyalty and commitment to the firm. ${ }^{5}$

Ability: Finally, even if frontline workers are given an opportunity to produce valuable local knowledge and share it with management AND have the appropriate incentive to do so, such useful local information may never be generated or shared widely in the firm in the absence of appropriate ability and skill of workers. As such, careful screening and recruitment are often an integral part of the High Performance Work System.

There is an enormous amount of previous empirical work by economists in this broad area and especially as it concerns the impact of such new work practices upon business performance. ${ }^{6}$ However, for the most part the empirical economics literature has not paid detailed attention to the actual process/mechanism through which HPWPs result in better enterprise performance. In other words, we know much about whether HPWPs improve

\footnotetext{
${ }^{5}$ In addition, job security can be an important necessary condition for the High Performance Work System. For instance, local knowledge accumulated through collaboration of frontline workers is often firmspecific in nature, and its value will be considerably lower outside of the firm. As such, in the absence of the practice of long-term employment, frontline workers will have less incentive to accumulate such firm-specific human capital. Furthermore, even if workers obtain valuable local knowledge, they may not share it in the absence of long-term employment. For example, performance-enhancing local knowledge discovered by frontline workers may result in labor-saving technological change. Imagine that a frontline worker has just discovered a way to perform his/her job more quickly and thus afford performing his/her co-worker's job as well. This may result in a loss of his/her co-worker's job or even worse his/her own job (which is now performed by his/her co-worker). Unless some degree of job security is credibly assured, the frontline worker will have an incentive not to reveal such performance-enhancing local information with management. For the importance of job security in the participatory employment system such as the Japanese system, see for example Levine (1995) and Carmichael and MacLeod (1993).

${ }^{6}$ See, for example, Huselid and Becker (1996), Dunlop and Weil (1996), Berg (1996), Ichniowski, Shaw and Prennushi (1997), Freeman, Kleiner, and Ostroff (2000), Cappelli and Neumark (2001), Hamilton, Nickerson and Owan (2003), Boning, Ichniowski , and Shaw (2007), Black and Lynch (2001, 2004), and Bartel (2004) for the U.S.; Jones and Kato (1995) and Kato and Morishima (2002) for Japan; Leoni, et. al. (2001) for Italy; Addison and Belfield (2000); Conyon and Freeman (2001); and DeVaro (2006), and Heywood, Jirjahn, and Wei (2008) for the U.K.; Eriksson (2003) for Denmark; Jones, Kalmi and Kauhanen (2006) for Finland; Bayo-Moriones, et. al. (2003) for Spain; and Zwick (2004) for Germany. In addition to the economics literature, there is a wealth of relevant literature in the field of management (see, for example, Lawler, Mohrman and Ledford, 1995 and Becker and Huselid, 1998).
} 
performance but we know little about how they do it. There are, however, a handful of studies that do make important steps in beginning to uncover such processes/mechanisms. First, a number of pioneering studies (e.g. Lazear, 2000, Kleiner and Helper, 2003, Fernie and Metcalf, 1999, Paarsh and Shearer, 1999, and Knez and Simester, 2001), focus on the effects on individual worker performance of the switch from time rates to piece rates or to performance pay, and provide direct evidence on the impact of performance pay upon individual worker behavior. A related line of work examines the effects on individual worker performance of the shift to team production (e.g. Batt, 1999 and Hamilton, Nickerson and Owan, 2002). Grant, Ichniowski and Shaw (2002) studies the impact of HPWPs on the nature of social networks and knowledge sharing among workers.

This paper contributes to this small yet growing literature on how HPWPs work. Specifically as we argued above, the High Performance Work System taps into each frontline worker's initiative, creativity and resourcefulness. To do so, the firm will need to foster a strong sense of empowerment and voice among workers by making each worker feel that: (i) his/her input counts; (ii) he/she is indeed provided with real substantive opportunities to participate and influence shopfloor decision making; and (iii) he/she actually take advantage of such opportunities to make suggestions to his/her boss concerning how to raise productivity and improve quality. In this paper, we investigate empirically whether HPWPs are indeed contributing to the development of such a strong sense of employee empowerment and voice in Japan and Korea.

Traditionally both Korean and Japanese firms subscribed to the East Asian model of industrial relations, characterized by long-term employment, seniority-based wage and promotion system, enterprise-level unions, and HPWPs. In recent years, however, Japan and Korea appeared to have parted; Japan maintaining its cooperative labor-management system in 
the main ${ }^{7}$ while Korea adopting the Anglo-American model of flexible labor market with more active external labor markets, accompanied by more confrontational and adversarial labormanagement relations. ${ }^{8}$

Section II introduces a new cross-national survey of workers, the Asian Worker Representation and Participation Survey which provides us with unique, reliable, and crossnational data for Japan and Korea (it is our intention to expand the scope of the Survey to other Asian countries in the future). In the following two sections, using the new data, we contrast between the two nations the strength of employee influence and voice on key decision making areas at the shopfloor level, employee demand for such influence and voice, and employee willingness to make productivity-enhancing and quality-improving suggestions. Sections V-VII present the ordered probit estimates on the possible impact of HPWPs upon employee voice and grassroots innovation, followed by concluding remarks.

\section{Asian Worker Representation and Participation Survey}

With full collaboration with Denki Rengo (Japanese Electrical, Electronic, Information Union), the Japanese team consisting of Chuma, Kato and Ohashi conducted the Japanese Worker Representation and Participation Survey during December 2003-January 2004. We held numerous meetings with experienced full-time research staff of Denki Rengo, and carefully developed the survey instrument, modeling after the U.S. Worker Representation and Participation Survey (Freeman and Rogers, 1999). After a pilot phase in which an earlier version of the instrument was tested, the questionnaire was finalized. In consultation with Denki Rengo's

\footnotetext{
${ }^{7}$ For the enduring nature of Japanese employment practices, see for instance Kato $(2001,2003)$ and Genda and Rebick (2000).

${ }^{8}$ See Cho (2005) as well as various papers presented at a recent international symposium SEEKING A VISION FOR LABOR-MANAGEMENT REFORM TO ENHANCE COMPETITIVENESS, sponsored by the Korea Institute for Industrial Economics and Trade, Seoul, Nov. 3, 2005 (http://www.kiet.re.kr/UpFile/newsbrief/1133775182921.pdf).
} 
research department, among 659,729 workers who belong to Denki Rengo, 3,000 workers were randomly selected and asked to participate in the Survey. The Survey was competently administered by Denki Rengo's research department, which is known for their expertise and long and successful experience on administrating such worker surveys. Notably, as in the case of numerous surveys that they administered in the past, the privacy of individual respondents was strictly protected throughout the survey process. Usable responses were obtained from 2,611 workers (a response rate of 87 percent). The impressive 87 percent response rate makes the unionized worker sample unusually reliable.

Our selection of the electrical, electronic and information industries was motivated in part by Denki Rengo's strong willingness to cooperate with us. It was, however, also motivated by the fact that the electrical, electronic and information industries are generally considered as one of the twin engines of Japan's export machine. 9 Whatever happens to these industries will have serious consequences on the overall health of the Japanese economy.

To construct a matching sample of workers in firms without union, we used one of the most reputable survey research firms in Japan, Nikkei Research Inc (a full service research company of Nihon Keizai Shinbun Group). Nikkei Research randomly selected 2,275 workers who work in non-unionized firms in the same electrical, electronic and information industries, and asked each worker to respond to the Japanese WRPS (a few questions were modified to reflect the fact that the sample universe is non-union workers). Usable responses were received from 445 workers (a response rate of 19.6 percent). The response rate of 19.6 percent is comparable to most surveys of similar nature in Japan.

${ }^{9}$ For instance, according to Japan Statistical Yearbook (2004), about 50 percent of total export from Japan was equally split between the electrical, electronic and information industries and the transportation equipment industry. We are currently planning to repeat the JWRPS in other industries in Japan. 
In 2006 the Korean team (Bae, Kato and Kim) carefully replicated the Japanese WRPS in Korea. Specifically, with full cooperation from the Korea Labor Institute and Metal Union, the team completed the Korean WRPS in February of 2006. Among all workers who belong to Metal Union, 2,400 workers were randomly chosen and asked to participate in the Survey. As in the case of the Japanese Survey, the privacy of individual respondents was strictly protected throughout the Korean survey process. Usable responses were obtained from 1,744 of them, amounting to yet another impressive response rate of 73 percent.

To construct a matching sample of workers in firms without union, like in the case of the Japanese Survey, the Korean research team randomly selected 822 workers who work in nonunionized firms in the same electrical, electronic and information industries. Usable responses were received from 574 of them (an equally impressive response rate of 70 percent). The unusually high response rate for the non-union sample makes the Korean WRPS especially attractive for comparative studies between union and non-union workers.

In short, by construction, we have an unusually comparable pair of datasets from the two important economies in Asia (the second and fifteenth largest economies in the world according to the most recent IMF ranking of GDP). In this paper, we exclude full-time union representatives who work for unions (and hence do not do any regular work for the firms) and are paid not by the firms but by unions. First, after all we are interested in the perspectives of regular workers not full-time union leaders. Second, such full-time union officials were overrepresented in the Japanese WRPS whereas no such over-representation is evident in the Korean WRPS. $^{10}$

\footnotetext{
${ }^{10}$ There were 521 full-time union officers in the initial Japanese sample where there were 172 in the initial Korean sample.
} 
The basic worker characteristics in both nations are presented in Table 1. As the table shows, Japanese workers are older than Korean workers (36 vs. 30). The Japanese tradition of "hiring new graduates" appears to be still live and well. The proportion of workers who joined their current firms after working for other firms (mid-career hires) as opposed to joining right from high-schools or colleges (new recruits) is still less than 25 percent in Japan. In contrast, the majority of Korean workers are mid-career hires. This finding is not inconsistent with the notion that lately Korea has been deviating from the East Asian Model with long-term employment more so than Japan.

Workers with some lower-level supervisory responsibilities are often union members (especially in Japan), and they are part of our target population. As shown in Table 1 (NORANK), a little less than 40 percent of Japanese workers in our sample do have such frontline supervisory responsibilities whereas only 20 percent of Korean workers hold such responsibilities. The difference in the proportion confirms that Japanese union shop tends to be more comprehensive than Korean union shop and that workers with college graduates and whitecollar workers are typically excluded from unions in Korea even from the very beginning of their careers whereas such college graduates and white-collar workers are included in Japanese unions until they become mid-level managers.

Table 1 shows that around 30 percent of Japanese workers have some union responsibilities at the grassroots level although all of them carry out their regular work as fulltime employees while fulfilling union responsibilities after hours except that they are allowed to leave their workplaces during regular hours when attending Shopfloor Committees as shop floor union representatives. Their hours absent from work due to participation in Shopfloor Committees are paid by unions. The proportion of workers with such workplace union 
responsibilities is only 1 percent in Korea since most of such front-line union leaders are of informal nature and they seldom considered themselves "union leaders".

Over 80 percent of Japanese workers are male whereas 56 percent of Korean workers are male. Furthermore, a higher proportion of Japanese workers has some education beyond high schools than Korean workers. The differences in educational attainment of workers between the two nations are reflected in the occupational composition of the labor force, i.e., over 50 percent of Korean workers in the sample are operators (or blue-collar) as compared to less than 25 percent of Japanese workers in the category. The difference in the proportion of operators between the two nations is again in most part due to the fact that Korean union shop is less comprehensive than Japanese union shop. ${ }^{11}$

Overall the Korean sample consists of older workers; more female workers; more bluecollar workers; less educated workers; more mid-career hires; and fewer shopfloor union representatives than the Japanese sample. Since both Japanese and Korean WRPS enjoyed unusually high response rates and we designed and administered the Korean WRPS, following the Japanese WRPS at every step of the way with bilingual staff in the team, we believe that the differences observed from our comparison of the Japanese and Korean samples reflect the population differences between the two nations.

\section{$\underline{\text { III. Employee Influence and Voice }}$}

Following Freeman and Rogers (1999), we focus on the following four key areas of shopfloor decision making: (i) JOB (deciding how to do job and organize the work); (ii) GOAL (setting goals for work group or department); (iii) TIME (setting work schedules, including

${ }^{11}$ For the non-union sample, a similar difference between the two nations is still observed since the non-union sample is matched with the union-sample in terms of worker characteristics. 
breaks, overtime and time off); and (iv) TRAINING (deciding on what training is needed for people in work group or department). The extent of employee influence and voice on JOB is measured by:

$\mathrm{SVOJOB}=3$ if the worker tells us that he/she has a lot of involvement and influence on deciding how to do his/her job and organize the work;

$=2$ if the worker tells us that he/she has some involvement and influence on deciding how to do his/her job and organize the work;

$=1$ if the worker tells us that he/she has little involvement and influence on deciding how to do his/her job and organize the work; and

$=0$ if the worker tells us that he/she has no involvement and influence on deciding how to do his/her job and organize the work.

SVOGOL, SVOTIM, and SVOTRA are defined likewise for the other three areas of shopfloor decision making respectively.

Similarly we measure how strong employee demand for such influence and voice on JOB is by constructing:

DVOJOB $=3$ if the worker tells us that he/she considers it very important to have a lot of involvement and influence on deciding how to do his/her job and organize the work;

$=2$ if the worker tells us that he/she considers it somewhat important to have a lot of involvement and influence on deciding how to do his/her job and organize the work;

$=1$ if the worker tells us that he/she considers it not very important to have a lot of involvement and influence on deciding how to do his/her job and organize the work; and 
$=0$ if the worker tells us that he/she considers it not at all important to have a lot of involvement and influence on deciding how to do his/her job and organize the work;

Likewise, we create DVOGOL, DVOTIM, and DVOTRA for the other three areas of shopfloor decision making respectively.

Finally, we create a variable PROPOS to capture the extent to which each worker takes advantage of the opportunities to influence shopfloor decision making and make suggestions to enhance productivity and improve produce quality to his/her boss. Specifically, PROPOS $=3$ if the worker tells us that he/she often makes suggestions to his/her boss concerning how to raise productivity and improve quality;

$=2$ if the worker tells us that he/she sometimes makes suggestions to his/her boss concerning how to raise productivity and improve quality;

$=1$ if the worker tells us that he/she rarely makes suggestions to his/her boss concerning how to raise productivity and improve quality; and $=0$ if the worker tells us that he/she never makes suggestions to his/her boss, concerning how to raise productivity and improve quality.

Table 2 shows the summary statistics of these influence/voice variables. The table suggests that workers in both nations have the strongest sense of voice on JOB, followed by TIME, GOAL and then TRAINING. Turning to differences between the two nations, Japanese workers have a much stronger sense of voice on JOB than the Korean counterparts whereas having a somewhat weaker sense of voice on TRAINING and GOAL.

Regarding employee demand for influence and voice, workers care most about JOB in both countries. Japanese workers are consistently more demanding than Korean workers in all four areas of shopfloor decision making. Finally, the table shows that Japanese workers tend to 
make suggestions to raise productivity and improve quality more frequently than their Korean counterparts.

\section{HPWPs}

As Levine and Tyson (1990) suggest, relatively greater job security and strong group cohesiveness of Japanese workers in large manufacturing companies in the postwar era point to an industrial relations system favorable to successful employee participation. In addition, steady economic growth, lower unemployment and stable financial corporate grouping point to an external environment favorable to successful employee participation.

Probably as a result of these favorable environments in the postwar Japanese economy, in particular in manufacturing, HPWPs diffused widely and were established firmly (Kato and Morishima, 2002). Indeed these practices became the hallmark of "Japanese management," which has been rousing (or requiring in some instances) many U.S. corporations to experiment with employee involvement and labor-management cooperation lately (see, for instance, Levine, 1995: 5). In short, the postwar Japanese economy (especially in manufacturing) clearly represents one of the most important examples of experimentation with HPWPs. ${ }^{12}$

In contrast, relatively limited information is available on the use of such practices in Korea (Yalabik, et. al.; 2008, Kato et al. 2005; Kim, 2004; Bae and Rowley, 2001). In particular, on our reading of the literature, the Korean WRPS provides the first comprehensive data at individual worker level on the incidence of participatory work practices in Korea. As such, the data will enable us for the first time to reveal how widely each of the key participatory employment practice is used among Korean workers as compared to the Japanese benchmark.

12 The economic slowdown in the 1990s and a rapidly aging workforce in Japan have allegedly been eroding the aforementioned participation-friendly environments. See Kato (2001, 2003), Chuma (2002), and Ohashi and Tachibanaki (1998) for evolving employment practices in Japan. 
As shown in Table 3, we consider six employment practices which are often considered key work practices of High Performance Work System of Japanese firms in the literature. ${ }^{13}$ Nearly 70 percent of Korean workers work for firms with Shopfloor Committees in which supervisors and employees on shop floor regularly discuss issues such as shop-floor operations and shop-floor environments. It is actually higher than the benchmark Japanese case (about 60 percent). However, it appears that once introduced, Japanese Shopfloor Committees are better attended by workers with about one in two Japanese workers always attending Shopfloor Committee meetings (SFCPART $=0.498)$ whereas only one in five Korean workers always attending (SFCPART=0.197)..

Over 80 percent of Korean workers work in firms with Small Group Activities such as quality control (QC) circles and Zero Defects in which small groups at the workplace level voluntarily set plans and goals concerning operations and work together toward accomplishing these plans and goals. In contrast, somewhat surprisingly, the majority of Japanese workers work in firms without Small Group Activities. This is in part due to the fact that a significant number of Japanese firms in the industries terminated Small Group Activities in recent years. ${ }^{14}$ Such terminations of Small Group Activities may pose a selection issue, i.e., poorly functioning Small Group Activities with little positive impact on employee voice may be more likely to be terminated than well-functioning Small Group Activities, resulting in an overestimation of the voice effect of Small Group Activities. We will account for this selection issue.

As in the case of Shopfloor Committees, however, the participation rate of workers in firms with Small Group Activities is remarkably high (85 percent) in Japan, confirming that

\footnotetext{
${ }^{13}$ See, for instance, Ohkusa and Ohtake (1997) for Profit Sharing Plans, Jones and Kato (1995) for Employee Stock Ownership Plans, Kato and Morishima (2002) for Joint Labor-Management Committees and Shopfloor Committees, and Kato (2003) for Small Group Activities.

${ }^{14}$ For a more detailed discussion on the declining Small Group Activities in Japan, see Chuma, Kato and Ohashi (2005).
} 
Japanese Small Group Activities are indeed broad-based. In stark contrast, the participation rate of Korean workers in firms with Small Group Activities is still less than 40 percent, pointing to the considerably narrower employee base of Korean Small Group Activities.

One of the core mechanisms for labor-management relations within a large Japanese firm is Joint Labor-Management Committees. Established at the top level (corporate and/or establishment level) and involving both management and union representatives, Joint LaborManagement Committees serve as a mechanism for employee participation/involvement at the top level, covering a large variety of issues ranging from basic business policies to working conditions. ${ }^{15}$ As Kato (2006) shows, the productivity effects of Joint Labor-Management Committees vary significantly, depending on how widely information shared in Joint LaborManagement Committees is disseminated to the rank and files. To this end, we calculate the proportion of workers who said that all information provided in Joint Labor-Management Committees is shared with them. ${ }^{16}$ About 7 percent of Korean workers said that all information provided in Joint Labor-Management Committees is indeed shared with them while nearly 9 percent of Japanese did, pointing to a somewhat narrower employee base of Korean Joint LaborManagement Committees.

Turning to financial participation schemes or group incentive pay, the pattern is reversed. Profit Sharing Plans which link at least a portion of employee pay to a measure of firm-wide performance (such as profit) are extremely wide spread among Japanese workers (over 80 percent of workers currently under Profit Sharing Plans) whereas the comparable figure for Korea is only 66 percent.

\footnotetext{
${ }^{15}$ See, for example, Kato (2006) for detailed institutional information on Joint Labor-Management Committees.

${ }^{16}$ For both nations, nearly all workers work for firms with Joint Labor-Management Committees. In Japan Joint Labor-Management Committees are one of the most established employment practices, and in Korea they are mandatory under the Korean law.
} 
We expect non-financial participation mechanisms such as Shopfloor Committees, Small Group Activities and Joint Labor-Management Committees to enhance an employee sense of involvement and influence since after all the main objective of these institutions is to foster employee voice.

On the other hand, we expect financial participation schemes (Profit Sharing Plans) to nurture employee interest and desire to have involvement and influence in shopfloor decisions, for a key function of financial participation schemes is to align the interest of workers with the interest of the firm. Such goal alignments will make employees more interested in firm performance and thus involvement and influence on firm decisions.

\section{HPWPs and Voice}

To test our hypothesis that HPWPs aiming at providing workers with opportunities to participate enhance employee voice, we specify the following Ordered Probit model:

$$
\begin{aligned}
& \operatorname{Pr}(\mathrm{SVOJOB}=\mathrm{j} \text { for } \mathrm{j}=0,1,2 \text {, and } 3)=F(\gamma \text { HPWP }, \mathrm{X} \beta) \\
& \operatorname{Pr}(\mathrm{SVOGOL}=\mathrm{j} \text { for } \mathrm{j}=0,1,2 \text {, and } 3)=\mathrm{F}(\gamma \mathrm{HPWP}, \mathrm{X} \beta) \\
& \operatorname{Pr}(\mathrm{SVOTIM}=\mathrm{j} \text { for } \mathrm{j}=0,1,2, \text { and } 3)=F(\gamma \text { HPWP }, \mathrm{X} \beta) \\
& \operatorname{Pr}(\mathrm{SVOTRA}=\mathrm{j} \text { for } \mathrm{j}=0,1,2 \text {, and } 3)=F(\gamma \text { HPWP }, \mathrm{X} \beta)
\end{aligned}
$$

As explained in Section III, SVOJOB, SVOGOL, SVOTIM and SVOTRA measure the strength of employee influence and voice on job, goal, schedule, and training respectively. For HPWP, as discussed above, we consider three major programs used widely by large firms in Japan and Korea: (i) SFC (=1 if the employee works in a firm with Shopfloor Committees, 0 otherwise);

(ii) SGA (=1 if the employee works in a firm with Small Group Activities, 0 otherwise); and (iii) JLMC (=1 if the employee believes that nearly all information shared in Joint LaborManagement Committees is made available to him/her, 0 otherwise). In addition, among those 
in firms with Shopfloor Committees, the data further allow us to create SFCPART (=1 if the employee almost always attends Shopfloor Committee meetings, 0 otherwise). Likewise, among those in firms with Small Group Activities, the data allow for the use of SGAPART (=1 if the employee participates in Small Group Activities, 0 otherwise).

The statistical significance of the estimated coefficient on each HPWP variable, $\gamma$ is of our main interest. That $\gamma>0$ supports our hypothesis that HPWPs enhance employee voice. $X_{i}$ is a vector of variables that may affect the voice variables. The WPRS provides us with a rich set of such control variables. First, whether or not the worker has some front-line supervisory responsibilities is likely to be correlated with his/her sense of influence and voice. As such, we consider a dummy variable NORANK ( $=1$ if the worker has no supervisory responsibilities, 0 otherwise).

A similar argument could be made for union responsibilities. Thus, to control for the possible effects on voice of having union responsibilities, we also consider a dummy variable ULBOT ( $=1$ if the worker is a grassroots-level union representative, 0 otherwise).

Conceivably the level of voice differs between different occupations. To control for possible cross-occupational differences in worker voice, we consider four occupational dummy variables: (i) BLUE ( $=1$ if the employee is working in production as an operator or a maintenance worker, 0 otherwise (omitted as a reference group in the regressions). (ii) ENGINEER ( $=1$ if the employee is an engineer or a scientist, 0 otherwise; (iii) STAFF ( $=1$ if the employee is an office staff member, 0 otherwise); and (iv) SALES ( $=1$ if the employee is a salesperson, 0 otherwise). 
Finally we include standard biographical characteristics such as AGE; MIDCAR; MALE; HIGHEDU; and UNION. ${ }^{17} \beta$ is a vector of unknown coefficients; and $\mathrm{F}($.$) is the standard$ normal cumulative distribution function.

Some students of employee involvement argue that the existence of mechanisms for voice can forestall the erosion of worker bargaining power (see, for instance, Hill, Indergaard, and Fujita, 1989), while others argue that these mechanisms aid in such erosion (see, for example, Parker and Slaughter, 1988). To shed light on such possible interplay between unions and employee involvement programs such as Shopfloor Committees, Small Group Activities, and Joint Labor-Management Committees, we will also estimate Eq. (1) - (4), augmented by an interaction term involving UNION and HPWP. For example, finding both the estimated coefficient on HPWP and the estimated coefficient on the interaction term involving UNION and HPWP to be positive and significant will imply that unions and employee involvement complement each other in enhancing employee voice (or HPWP will enhance voice AND the voice-enhancing effect of HPWP will be greater in the presence of unions than in their absence).

The maximum likelihood estimates of Eq. (1)-Eq. (4) with Shopfloor Committee as a HPWP variable are reported in Tables 4-1 and 4-2. The estimated coefficients on SFC are all positive and statistically significant at the 1 percent level for both Japan and Korea. As such, we find consistent evidence supporting our hypothesis that workers in firms with Shopfloor Committee exhibit significantly stronger voice than other workers. This significant linkage between Shopfloor Committees and voice is found for all four areas of shopfloor decision making and for both Japan and Korea. In addition, to test the statistical significance of the differences between Japan and Korea, we create a dummy variable, KOREA (=1 if the worker works for Korean firms, 0 otherwise). We then pool the Japanese and Korean samples and re-

\footnotetext{
${ }^{17}$ Tenure is not included, for it is highly correlated with AGE.
} 
estimate the ordered probit model, augmented by a full set of interaction terms involving each independent variable and KOREA. The estimated coefficients on such interaction terms reveal that Japanese Shopfloor Committees appear to have stronger impact on employee voice on goal and training than Korean Shopfloor Committees. The finding appears to be consistent with: (i) our earlier finding that Japanese Shopfloor Committees are more broad-based than Korean Shopfloor Committees (the majority of Japanese workers in firms with Shopfloor Committees almost always attending Shopfloor Committees while only one in five Korean workers in firms with Shopfloor Committees do); and (ii) evidence from comparative field research at Japanese and Korean manufacturing firms (Kato, et. al., 2005).

Many of the control variables also turn out to be statistically significantly related to worker voice. Specifically, voice is found to be consistently greater for both Japanese and Korean workers with supervisory responsibilities; for male workers; and for workers with union responsibilities.

As discussed above, we also estimated Eq. (1) - (4), augmented by the interaction term, UNION*SFC to further explore the possible interplay between unions and Shopfloor Committees. As shown in Table 4.3, overall we do not find any systematic evidence on the interplay between unions and Shopfloor Committees. The only exception is the Korean result on voice on training, i.e., the positive and significant effect on voice on training of Shopfloor Committees is found significantly smaller in the presence of unions than in their absence in Korea. Insofar as the effect on voice on training of Korean Shopfloor Committees is concerned, unions and shopfloor employee involvement might be working against each other. However, since we do not find such a negative relationship between Shopfloor Committees and unions for voice on any of the remaining three important areas of decision (jobs, goals, and scheduling) in 
Korea and find no such relationship at all for Japan, we ought not to draw any definitive conclusion.

Tables 5-1 and 5-2 present similar results when using SGA as alternative HPWP variables. Specifically, we find consistently for all four areas of decision making and for both Japan and Korea that the estimated coefficients on SGA are positive and statistically significant at the 1 percent level, supporting that workers in firms with Small Group Activities are more likely to have strong voice (or the significant impact on voice of Small Group Activities). As in the case of Shopfloor Committees, we find some evidence for a greater effect of Japanese Small Group Activities upon voice on TRAINING which is consistent with our earlier finding that Japanese Small Group Activities are more broad-based than Korean Small Group Activities (85 percent of Japanese workers in firms with Small Group Activities are involved with Small Group Activities while the Korean figure is only 40 percent) as well as evidence from comparative field research (Kato, et. al., 2005).

As discussed earlier, the termination of Small Group Activities ceased to be a rare event in recent years, especially in Japan. If poorly-functioning Small Group Activities with little positive effect on employee voice are more likely to be terminated than well-functioning Small Group Activities, the estimated positive effect on voice of Small Group Activities will be biased upward, or overstating the "true" effect on voice of Small Group Activities. Fortunately the Survey asks each respondent whether he/she works in a firm that does not have Small Group Activities currently yet used to have them. To use this information, we create an alternative Small Group Activities variable, SGAALL=1 if a worker works in a firm that has Small Group Activities currently or used to have Small Group Activities, 0 otherwise, and reestimate Eq. (1) (4), using SGAALL instead of SGA. As shown in Table 5-3, reassuringly the estimated 
coefficients on SGAALL are broadly consistent with those on SGA as reported in Tables 5-1 and $5-2$, suggesting that the aforementioned selection bias may not be too severe. ${ }^{18}$

As we did for Shopfloor Committees, we also explore the possible interplay between unions and Small Group Activities by estimating Eq. (1) - (4), augmented by the interaction term, UNION*SGA. Again, we failed to find any systematic evidence for the interplay between unions and Small Group Activities (see Table 5-4). The only exception is that in Korea unions appear to have a negative effect on voice on training (the estimated coefficient on UNION is negative and significant) yet such a negative union effect on voice is tempered by the use of Small Group Activities (the estimated coefficient on UNION*SGA is positive and significant).

The results for Joint Labor-Management Committees as shown in Tables 6-1 and 6-2 are largely consistent with those for Shopfloor Committees and Small Group Activities although slightly weaker. Thus, the estimated coefficients on JLMC are positive for all eight cases (four areas of decision making times two countries), and statistically significant for three out of four areas in Korea (job, goal and schedule) and two out of four areas in Japan (job and schedule). Workers in firms with full-information sharing Joint Labor-Management Committees are more likely to have stronger voice than other workers. Again, we estimate Eq. (1) - (4) with UNION*JLMC added and find no systematic evidence for the interplay between unions and Joint Labor-Management Committees with full information sharing (Table 6-3). For Japan, however, concerning employee voice on goal setting and scheduling, the positive voice effect of Joint Labor-Management Committees is found greater for workers in non-union firms than for workers in unionized firms (as implied by the negative and significant coefficients on

\footnotetext{
${ }^{18}$ The estimated coefficient on voice on training of Korean Small Group Activities appears to fall discernibly and become insignificant when SGAALL is used. However, the estimated coefficient on voice on training of Korean Small Group Activities when SGA used was significant only at the 10 percent level to begin with, and a somewhat large standard error makes it difficult to draw any definitive conclusion for the case of voice on training in Korea.
} 
UNION*JLMC). Our finding of the greater voice effect of Joint Labor-Management Committees in the non-union sector as compared to the union sector is not inconsistent with the literature on Japanese industrial relations which tends to point to the importance of Joint Labor-Management Committees as a de facto collective bargaining mechanism for workers in non-union firms in Japan (see, for instance, Koike, 1977).

The most recent Labor-Management Communication Survey (conducted by the Ministry of Health, Labor and Welfare in 2004) also provides some institutional information on Joint Labor-Management Committees, which appears to be supportive of our finding. ${ }^{19}$ For example, according to the Survey, for non-union establishments, fully 73 percent of all establishments with Joint Labor-Management Committees consider "wages and bonuses" a regular item to be discussed during their Joint Labor-Management Committee meetings (the figure for unionized establishment is 91 percent). Likewise, 75 percent of all non-union establishments with Joint Labor-Management Committees consider "overtime premium" a regular discussion item; 88 percent "fringe benefits"; and 91 percent "work schedules" (the figures for unionized establishments are 80 percent; 87 percent; and 93 percent respectively). Furthermore, 73 percent of all non-union establishments with Joint Labor-Management Committees have at least one of their employee representatives elected by employees. Though Joint Labor-Management Committees in the non-union sector lacks the right to strike, and hence their bargaining power is in principle weaker than formal unions, they appear to provide Japanese workers in the nonunion sector with a potentially important opportunity to voice.

Next, to see if the results change much when we consider all three HPWPs together, we estimate the ordered probit models with SFC, SGA and JLMC considered simultaneously. As

\footnotetext{
${ }^{19}$ The sample universe of this survey is establishments of firms with more than 30 workers, and has been enjoying an unusually high response rate (around 70 percent).
} 
shown in Tables 7-1 and 7-2, the significant linkage between HPWPs and voice is mostly robust to such nested specifications. Specifically, holding SGA and JLMC constant, workers in firms with Shopfloor Committees are still found to have significantly stronger voice on all four areas of shopfloor decision making. This finding is unique neither to Japan nor to Korea. Likewise, holding SFC and JLMC constant, we still find that workers in firms with Small Group Activities are more likely to have stronger voice (on all four areas for Japan and on two areas for Korea). Finally, after controlling for SFC and SGA, workers in firms with full information sharing Joint Labor-Management Committees are still found to have stronger influence (on three of four areas for Korea and two out of four areas for Japan).

Finally, to see if active participants in Shopfloor Committees and Small Group Activities differ significantly in their senses of voice from other workers in firms with such programs, we focus on all workers in firms with Shopfloor Committees (Small Group Activities) and estimate the ordered probit models with SFCPART (SGAPART) as a HPWP variable. Tables 8-1 and 8-2 report the maximum likelihood estimates of Eq. (1)-Eq. (4) with SFCPART as a HPWP variable and Tables 9-1 and 9-2 with SGAPART as a HPWP variable. The estimated coefficients on SFCPART are positive and significant at the 1 percent level for all four areas of shopfloor decision making and for both nations except for one case (significant at the 10 percent level for voice on schedule for Korea). Participants in Shopfloor Committees are indeed more likely to have stronger voice on all four areas and for both countries. ${ }^{20}$ We also find evidence that the association between SFCPART and voice on schedule is significantly stronger in Japan than in Korea.

${ }^{20}$ Causal interpretations are particularly difficult here, for it is plausible that workers with strong senses of voice are more likely to participate in those programs. 
Similar results are found for SGAPART. The estimated coefficients on SGAPART are positive and significant at least at the 10 percent level for all four areas of decision making and for both countries. Again there is evidence that participants in Japanese Small Group Activities are more likely to have stronger voice on training than those in Korean Small Group Activities.

\section{$\underline{\text { VI. Demand for Voice and Group Incentive Pay }}$}

To test whether HPWPs aiming at providing workers with group incentive pay such as Profit Sharing Plans make workers desire stronger voice, we specify the following Ordered Probit model:

$$
\begin{aligned}
& \operatorname{Pr}(\text { DVOJOB }=j \text { for } j=0,1,2, \text { and } 3)=F(\gamma P S P, X \beta) \\
& \operatorname{Pr}(\text { DVOGOL }=j \text { for } j=0,1,2, \text { and } 3)=F(\gamma P S P, X \beta) \\
& \operatorname{Pr}(\text { DVOTIM }=j \text { for } j=0,1,2, \text { and } 3)=F(\gamma P S P, X \beta) \\
& \operatorname{Pr}(\text { DVOTRA }=j \text { for } j=0,1,2 \text {, and } 3)=F(\gamma P S P, X \beta)
\end{aligned}
$$

DVOJOB, DVOGOL, DVOTIM, and DVOTRA capture the strength of employee demand for influence and voice on job, goal, schedule and training (see Section III for precise definitions). For HPWP aiming at group incentive, we consider the most widely used program, Profit Sharing Plans, $\mathrm{PSP}(=1$ if the employee's compensation includes profit sharing bonus which is linked to firm performance, 0 otherwise). For control variables, $\mathrm{X}$, we use the same set of variables used in the previous section. Finally, $\beta$ is a vector of unknown coefficients; and $F($.$) is the standard$ normal cumulative distribution function.

Tables 10-1 and 10-2 summarize the maximum likelihood estimates of Eq. (5)-Eq. (8). For Japanese workers, the estimated coefficients on PSP are positive and significant at the 5 percent level when we use voice on job (DVOJOB) in the dependent variable and at the 1 percent level when voice on training (DVOTRA) used. On the other hand, we find no 
statistically significant linkage between Profit Sharing Plans and demand for voice in any area of shopfloor decision making for Korean workers. The contrast between the two nations appears to be consistent with our field research at Japanese and Korean manufacturing firms which demonstrates the narrower scope and smaller magnitude of Profit Sharing Plans in Korea as compared to Japan. Most consistent among results on control variables is negative associations between demand for voice and NORANK, confirming that workers with supervisory responsibilities tend to demand stronger voice in both nations.

\section{HPWPs and Employee Suggestions}

We conclude our analysis by examining whether HPWPs aiming at providing front-line workers with grassroots innovation opportunities, combined with group incentive pay (Profit Sharing Plans), lead to active grassroots innovation. To this end, we estimate the following ordered probit model:

$$
\operatorname{Pr}(\operatorname{PROPOS}=\mathrm{j} \text { for } \mathrm{j}=0,1,2 \text {, and } 3)=\mathrm{F}(\mathrm{HPWP} \gamma, \mathrm{X} \beta)
$$

PROPOS measures the frequency of employee suggestions to raise productivity and improve product quality as explained in Section III..$^{21}$ For HPWPs, as we did in the previous sections, we consider Shopfloor Committees, Small Group Activities and Joint Labor-Management Committees with full information sharing as HPWPs designed to create opportunities to innovate at the grassroots level; and Profit Sharing Plans as a group incentive scheme. We use the same set of control variables, $\mathrm{X}$.

It is self-explanatory how Shopfloor Committees and Small Group Activities generate opportunities for front-line workers to make productivity-enhancing and quality-improving

${ }^{21}$ Ideally we should also use a variable capturing the quality of employee suggestions. Unfortunately we have no reliable data on such suggestion quality. 
suggestions. Joint Labor-Management Committees are, however, a form of representative participation, and it is not obvious how they help continuous improvement at the grassroots level.

To illustrate vividly how well-functioning Joint Labor-Management Committees with broad-employee base can facilitate front-line innovation activities, let us introduce one of our Korean field research sites, $\mathrm{K}$-firm. K-firm is a large manufacturing firm and workers from this firm are respondents to our Korean Worker Representation and Participation Survey. First, Kfirm has Joint Labor-Management Committees at the headquarter level as well as at the plant level. The headquarter level Joint Labor-Management Committee meets formally every quarter as the Korean law requires while the plant-level Joint Labor-Management Committee meets formally every month. The headquarter-level Joint Labor-Management Committee consists of equal number of management and labor representatives as the law mandates (10 council members from each side). The plant-level Joint Labor-Management Committee consists of plant manager, plant HR director, and other managers as management representatives and plantlevel union leaders as labor representatives (line supervisors are often plant-level union representatives).

The plant-level Joint Labor-Management Committee meetings are often devoted to serious discussions on how to enhance productivity, improve product quality, and out-compete its major international competitors (mostly Japanese). According to the General Secretary of Kfirm's union, factor-level union leaders, many of whom are not full time union leaders, spend on average 10 hours a month on preparing for monthly factory-level Joint Labor-Management Committee meetings. The company allows them to do this during their regular working hours. In other words, as in the case of full-time union leaders, these shopfloor union leaders are also paid for their Joint Labor-Management Committee-related activities by the company. 
Recently K-firm's Joint Labor-Management Committees spent much time dealing with a recent product recall incidence. A serious product defect and reported consumer injuries caused by the defect were revealed to labor representatives for Joint Labor-Management Committee before the public disclosure of such potentially devastating information. Labor representatives for Joint Labor-Management Committee using both formal and informal channels solicited ideas from general union membership (front-line workers) how to deal with the company crisis. Based on various ideas suggested by local members, labor representatives for Joint Labor-Management Committee subsequently made two specific proposals to management representatives: (i) volunteering union representatives (shop stewards) to join the firm's recall team as servicemen; and (ii) running a newspaper ad apologizing for the product defect. These proposals were accepted and implemented by the firm successfully. K-firm's Joint Labor-Management Committees proved to be a potent catalyst for such effective "bottom-up" solutions (Note that these solutions originated from front-line workers).

The maximum likelihood estimates of Eq. (9) are presented in Table 11. The estimated coefficients on SFC, SGA and PSP are positive and significant at the 1 percent level for Japanese workers. Japanese workers with the presence of group incentive created by Profit Sharing Plans and grassroots innovation opportunities furnished by Shopfloor Committees and Small Group Activities are indeed found to be more frequently making productivity-enhancing and qualityimproving suggestions than other Japanese workers. For Korean workers, to be consistent with the results in the previous section, we find no statistically significant link between group incentive pay (Profit Sharing Plans) and the frequency of employee suggestions. On the other hand, the estimated coefficients on SFC and JLMC are positive and statistically significant at the 1 percent level, suggesting that Korean workers with local innovation opportunities created by 
Shopfloor Committees and Joint Labor-Management Committees are more prone to make suggestions to raise productivity and improve quality than other Korean workers.

The difference in the impact on PROPOS of SGA, JLMC and PSP between the two nations turns out to be statistically significant at the 1 percent level, indicating that Japanese Small Group Activities and Profit Sharing Plans are more effective in promoting employee suggestions than Korean Small Group Activities and Profit Sharing Plans whereas Korean Joint Labor-Management Committees with full information sharing are more effective than their Japanese counterparts.

Finally, note that for Japan the estimated coefficient on JLMC is not as significant as the estimated coefficients on SFC, SGA and PSP yet it is negative, pointing to a negative association between JLMC and PROPOS, holding SFC, SGA and PSP as well as all other control variables constant. The negative coefficient on JLMC for the Japanese sample is significant only at the 10 percent level, and is likely to be generated by a small number of unusual firms in Japan that use Joint Labor-Management Committees with full information sharing yet lack all other popular employee involvement programs such as Shopfloor Committees and Small Group Activities as well as profit sharing plans which are extremely popular in the electrical, electronic and information industries in Japan. As such, we ought not to over-interpret the result. With this caveat in mind, however, there are two possible interpretations of the observed contrast in the effectiveness of Joint Labor-Management Committees between the two nations, i.e., the positive and highly significant effect on the frequency of employee suggestions for productivity enhancement and quality improvement is found for Joint Labor-Management Committees in Korea, while no such positive effect for Japanese Joint Labor-Management Committees (in fact we find a negative effect though not highly significant). 
For those who argue that employee involvement programs such as Shopfloor Committees and Small Group Activities lead to an erosion of union bargaining power (see, for example, Parker and Slaughter, 1988), such a finding would indicate that Japanese unions have been weakened as a result of Japan’s highly-developed employee involvement programs, that Japanese workers find the representative bodies (Joint Labor-Management Committees and union officials as labor representatives to the Committees in particular) do not function as well as the management-controlled programs such as Small Group Activities. Such an erosion of union bargaining power has not materialized in Korea, for employee involvement programs in Korea are still somewhat in their early stages.

For those who are more sanguine about employee involvement programs, the finding can be viewed as a sort of “participation crowding out”. Specifically, once Japanese workers are provided with ample opportunities to participate via well-established Shopfloor Committees and Small Group Activities, representative participation such as Joint Labor-Management Committees may become redundant and less effective means to provide such local innovation opportunities. $^{22}$ For Korea where Shopfloor Committees and Small Group Activities still have weaker employee base and hence are less effective, Joint Labor-Management Committees do not overlap with Shopfloor Committees and Small Group Activities and remain effective in fostering employee involvement in firm performance activities.

\section{Concluding Remarks}

${ }^{22}$ Our finding is congruous to Kato and Owan (2009) which suggest that Japanese Joint LaborManagement Committees may be used to facilitate vertical control by the management, and hence that teambased instruments for shopfloor information sharing and local problem solving with active and frequent employee input) are less likely to be adopted in firms with Joint Labor-Management Committees. 
Using a unique new survey of Japanese and Korean workers in the electrical, electronic and information industries, this paper has presented the first comparative evidence on (i) the strength of employee influence and voice; (ii) the use of HPWPs (High Performance Work Practices); and (iii) linkage between the use of such HPWPs and the strength of employee influence and voice, and consequently the extent of innovation at the grassroots level. In so doing, this paper contributes to a small yet growing empirical literature which tries to go beyond a traditional question of whether or not HPWPs improve firm performance, and understand the actual process and mechanism through which HPWPs result in better enterprise performance. The High Performance Work System taps into each front-line worker's initiative, creativity and resourcefulness. To do so, the firm will need to foster a strong sense of empowerment and voice among workers by making each worker feel that: (i) his/her input counts; (ii) he/she is indeed provided with real substantive opportunities to participate and influence shopfloor decision making; and (iii) he/she actually take advantage of such opportunities to make suggestions to his/her boss concerning how to raise productivity and improve quality. We have found systematic evidence suggesting that HPWPs are indeed contributing to the development of such a strong sense of employee empowerment and voice in Japan and Korea.

Traditionally both Korean and Japanese firms subscribed to the East Asian model of industrial relations, characterized by long-term employment, seniority-based wage and promotion system, enterprise-level unions, and HPWPs. In recent years, however, Japan and Korea appeared to have parted; Japan maintaining its cooperative labor-management system in the main while Korea adopting the Anglo-American model of flexible labor market with more active external labor markets, accompanied by more confrontational and adversarial labormanagement relations. We do not have evidence in support of such divergence between the two countries. Overall, we find more commonalities than differences between Japan and Korea, 
pointing to the continued importance of HPWPs in those two East Asian economies which are almost as large as the EU economies.

While derived from the unusually reliable and representative survey with over 75 percent response rates with detailed information on each respondent, our data are still cross-sectional. As such, our estimates are subject to usual shortcomings of cross-sectional data such as unobserved worker heterogeneity. Furthermore, there is a standard external validity issue. To increase the external validity of our findings, we plan to expand the scope of our research project to include other Asian economies, in particular China and other industries, especially motor vehicles. 
References

Addison, John T. and Clive R. Belfield. 2000. "The Impact of Financial Participation and Employee Involvement on Financial Performance: A Re-Estimation Using the 1998 WERS." Scottish Journal of Political Economy 47 (November):571-83.

Appelbaum, Eileen; Thomas Bailey; Peter Berg and Arne L. Kalleberg. 2000. Manufacturing Advantage: Why High-Performance Work Systems Pay Off. Ithaca and London: Cornell University Press, ILR Press.

Bae, Johngseok and Chris Rowley. 2001. "The Impact of Globalization on HRM: The Case of South Korea." Journal of World Business 36 (Winter):402-28.

Bartel, Ann P. 2004. "Human Resource Management and Organizational Performance: Evidence from Retail Banking." Industrial and Labor Relations Review 57 (January):181-203.

Batt, Rosemary. 1999. "Work Organization, Technology, and Performance in Customer Service and Sales." Industrial and Labor Relations Review 52 (July):539-64.

Bayo-Moriones, José Alberto; Pedro Javier Galilea-Salvatierra and Javier Merino-Díaz de Cerio. 2003. "Participation, Cooperatives and Performance: An Analysis of Spanish Manufacturing Firms." In Determinants of the Incidence and the Effects of Participatory Organizations: Advances in the Economic Analysis of Participatory and Labor-Managed Firms, edited by T. Kato and J. Pliskin, pp. 31-56. Amsterdam: Elsevier/JAI.

Becker, Brian E. and Mark A. Huselid. 1998. "High Performance Work Systems and Firm Performance: A Synthesis of Research and Managerial Implications." In Research in Personnel and Human Resources Management., edited by G. R. Ferris, pp. 53-101. Stamford, Conn. and London: JAI Press.

Berg, Peter. 1996. "The Performance Effects of Modular Production in the Apparel Industry." Industrial Relations 35 (July):356-73.

Black, Sandra E. and Lisa M. Lynch. 2001. "How to Compete: The Impact of Workplace Practices and Information Technology on Productivity." Review of Economics and Statistics 83 (August):434-45. . 2004. "What's Driving the New Economy? The Benefits of Workplace Innovation." Economic Journal 114 (February):F97-116.

Boning, Brent; Casey Ichniowski and Kathryn Shaw. 2007. "Opportunity Counts: Teams and the Effectiveness of Production Incentives." Journal of Labor Economics 25 (October):61350.

Cappelli, Peter and David Neumark. 2001. "Do "High-Performance" Work Practices Improve Establishment-Level Outcomes?" Industrial and Labor Relations Review 54 (July):73775.

Carmichael, H. Lorne and W. Bentley MacLeod. 1993. "Multiskilling, Technical Change and the Japanese Firm." Economic Journal 103 (January):142-60.

Cho, Joonmo. 2005. "Human Resource Management, Corporate Governance Structure and Corporate Performance in Korea: A Comparative Analysis of Japan, Us and Korea." Japan and the World Economy 17 (December):417-30.

Chuma, A. Hiroyuki; Takao Kato and Isao Ohashi. 2005. "Worker Discontent, Voice and EI Programs in Japan: Evidence for the Japanese Worker Representation and Participation Survey." Working Paper No. 235. Center on Japanese Economy and Business, Columbia Business School.

Chuma, Hiroyuki. 2002. "Employment Adjustments in Japanese Firms During the Current Crisis." Industrial Relations 41 (October):653-82. 
Conyon, Martin J. and Richard B. Freeman. 2001. "Shared Modes of Compensation and Firm Performance: UK Evidence." Working Paper No. 8448. Cambridge, MA: National Bureau of Economic Research.

DeVaro, Jed. 2006. "Teams, Autonomy, and the Financial Performance of Firms." Industrial Relations 45 (April):217-69.

Dunlop, John T. and David Weil. 1996. "Diffusion and Performance of Modular Production in the U.S. Apparel Industry." Industrial Relations 35 (July):334-55.

Eriksson, Tor. 2003. "The Effects of New Work Practices - Evidence from Employer-Employee Data." In Determinants of the Incidence and the Effects of Participatory Organizations: Advances in the Economic Analysis of Participatory and Labor-Managed Firms, edited by T. Kato and J. Pliskin, pp. 3-30. Amsterdam: Elsevier/JAI.

Fernie, Sue and David Metcalf. 1999. "It's Not What You Pay It's the Way That You Pay It and That's What Gets Results: Jockeys' Pay and Performance." Labour 13 385-411.

Freeman, Richard B. and Joel Rogers. 1999. What Workers Want. Ithaca and London: Cornell University Press, ILR Press.

Freeman, Richard; Morris Kleiner and Cheri Ostroff. 2000. "The Anatomy of Employee Involvement and Its Effects on Firms and Workers." Working Paper No. 8050. Cambridge, MA: National Bureau of Economic Research.

Gant, Jon; Casey Ichniowski and Kathryn Shaw. 2002. "Social Capital and Organizational Change in High-Involvement and Traditional Work Organizations." Journal of Economics and Management Strategy 11 289-328.

Genda, Yuji and Marcus E. Rebick. 2000. "Japanese Labour in the 1990s: Stability and Stagnation." Oxford Review of Economic Policy 16 (Summer):85-102.

Hamilton, Barton H.; Jack A. Nickerson and Hideo Owan. 2003. "Team Incentives and Worker Heterogeneity: An Empirical Analysis of the Impact of Teams on Productivity and Participation." Journal of Political Economy 111 (June):465-98.

Helper, Susan. 1998. "Complementarity and Cost Reduction: Evidence from the Auto Supply Industry." Working Paper No. 6033 (revised). Cambridge, MA: National Bureau of Economic Research.

Heywood, John S.; Uwe Jirjahn and Xiangdong Wei. 2008. "Teamwork, Monitoring and Absence." Journal of Economic Behavior \& Organization 68 (December):676-90.

Hill, Richard Child ; Michael Indergaard and Kuniko Fujita. 1989. "Flat Rock, Home of Mazda: The Social Impact of a Japanese Company on an American Community." In The Auto Industry Ahead: Who's Driving?, edited by P. J. Arnesen, pp. 69-131. Ann Arbor: Center for Japanese Studies, The University of Michigan.

Huselid, Mark A. and Brian E. Becker. 1996. "Methodological Issues in Cross-Sectional and Panel Estimates of the Human Resource-Firm Performance Link." Industrial Relations 35 (July):400-22.

Ichniowski, Casey; Kathryn Shaw and Giovanna Prennushi. 1997. "The Effects of Human Resource Management Practices on Productivity: A Study of Steel Finishing Lines." American Economic Review 87 (June):291-313.

Jones, Derek C.; Panu Kalmi and Antti Kauhanen. 2006. "Human Resource Management Policies and Productivity: New Evidence from an Econometric Case Study." Oxford Review of Economic Policy 22 (Winter):526-38.

Jones, Derek C. and Takao Kato. 1995. "The Productivity Effects of Employee Stock-Ownership Plans and Bonuses: Evidence from Japanese Panel Data." American Economic Review 85 (June):391-414. 
Kato, Takao. 2001. "The End of Lifetime Employment in Japan? Evidence from National Surveys and Field Research." Journal of the Japanese and International Economies 15 (December):489-514. . 2006. "The Nature, Scope and Effects of Joint Labor-Management Committees in Japan." In Participation in the Age of Globalization and Information, edited by P. Kalmi and M. Klinedinst, pp. 55-80. Amsterdam: Elsevier/JAI. . 2003. "The Recent Transformation of Participatory Employment Practices." In NBER Conference Report Labor Markets and Firm Benefit Policies in Japan and the United States, edited by S. Ogura, T. Tachibanaki and D. Wise, pp. 39-80. Chicago: University of Chicago Press.

Kato, Takao and Owan Hideo. 2009. "Market Characteristics, Intra-Firm Coordination, and the Choice of Human Resource Management Systems: Evidence from New Japanese Data." Revised version of IZA Discussion Paper 3105.

Kato, Takao; Ju Ho Lee; Kang-Sung Lee and Jang-Soo Ryu. 2005. "Employee Participation and Involvement in Korea: Evidence from a New Survey and Field Research." International Economic Journal 19 251-81.

Kato, Takao and Motohiro Morishima. 2002. "The Productivity Effects of Participatory Employment Practices: Evidence from New Japanese Panel Data." Industrial Relations 41 (October):487-520.

Kim, Dong-Bae. 2004. "Chapter 7 Human Resource Management." In Labor in Korea, 19872002 (Forthcoming), edited by W. Lee, pp. 243-83. Seoul: Korea Labor Institute.

Kleiner, Morris and Susan Helper. 2003. "Changing Incentives for Production Employees: Impacts on Establishment Economic Outcomes and Worker Satisfaction." Paper presented at the 55th IRRA meeting, Washington, D.C. . 2003. "Changing Incentives for Production Employees: Impacts on Establishment Economic Outcomes and Worker Satisfaction." Working Paper No.

Kochan, Thomas and Paul Osterman. 1994. Mutual Gains Enterprise: Forging a Winning Partnership among Labor, Management, and Government (Hardcover). Harvard Business School Press.

Koike, Kazuo. 2005. Shigoto No Keizaigaku (Economics of Work). Tokyo: Toyo Keizai. . 1977. Shokuba No Rodokumiai to Sanka (Unions at Workplace and Participation). Tokyo: Toyo Keizai (Oriental Economist).

Lawler, Edward E; Susan A. Mohrman and Gerald Ledford. 1995. Creating High Performance Organizations. San Francisco: Jossey-Bass.

Lazear, Edward P. 2000. "Performance Pay and Productivity." American Economic Review 90 $1346-61$.

Leoni, Riccardo ; Annalisa Cristini; Sandrine Labory and Alessandro Gaj. 2001. "New Work Practices in Italy - Adoption and Performance Effects." Paper presented at the International Conference on Organizational Design, Management Styles and Firm Performance, University of Bergamo, Bergamo, Italy.

Levine, David I. 1995. Reinventing the Workplace: How Business and Employees Can Both Win. Washington, D.C.: Brookings Institution.

Levine, David I. and Laura D'Andrea Tyson. 1990. "Participation, Productivity and the Firm's Environment." In Paying for Productivity, edited by A. S. Blinder, pp. 183-236. Washington, D.C.: Brookings Institution.

Ohashi, Isao and Toshiaki Tachibanaki, eds. 1998. Internal Labour Markets, Incentives and Employment. New York, London: St. Martin's Press/Macmillan Press. 
Paarsch, Harry J. and Bruce S. Shearer. 1999. "The Response of Worker Effort to Piece Rates: Evidence from the British Columbia Tree-Planting Industry." Journal of Human Resources 34 643-67.

Parker, Mike and Jane Slaughter. 1988. Choosing Sides: Unions and the Team Concept. Boston: South End Press.

Yalabik, Zeynep Y.; Shyh-Jer Chen; John Lawler and Kwanghyun Kim. 2008. "HighPerformance Work System and Organizational Turnover in East and Southeast Asian Countries." Industrial Relations 47 (January):145-52.

Zwick, Thomas. 2004. "Employee Participation and Productivity." Labour Economics 11 (Special Issue):715-40. 
Table 1 Differences in Worker Characteristics between Japan and Korea

\begin{tabular}{|c|c|c|c|c|c|c|c|}
\hline \multirow[b]{2}{*}{ Variable } & \multicolumn{3}{|c|}{ Japan } & \multicolumn{3}{|c|}{ Korea } & \multirow[b]{2}{*}{ Japan-Korea difference } \\
\hline & $\mathrm{N}$ & Mean & Std Dev & $\mathrm{N}$ & Mean & Std Dev & \\
\hline AGE & 2489 & 36.119 & $\begin{array}{ll}7.857 \\
\end{array}$ & 1955 & 30.293 & \begin{tabular}{|c|}
7.747 \\
\end{tabular} & *** \\
\hline MIDCAR & 2514 & 0.226 & 0.418 & 1964 & 0.535 & 0.499 & $* * *$ \\
\hline MALE & 2520 & 0.815 & 0.389 & 2076 & 0.560 & 0.497 & $* * *$ \\
\hline HIGHEDU & 2511 & 0.537 & 0.499 & 2025 & 0.265 & 0.441 & $* * *$ \\
\hline NORANK & 2535 & 0.628 & 0.484 & 1998 & 0.807 & 0.395 & $* * *$ \\
\hline ULBOT & 2490 & 0.323 & 0.468 & 1940 & 0.010 & 0.099 & $* * *$ \\
\hline BLUE & 2505 & 0.238 & 0.426 & 1913 & 0.520 & 0.500 & $* * *$ \\
\hline TECH & 2505 & 0.397 & 0.489 & 1913 & 0.376 & 0.485 & \\
\hline STAFF & 2505 & 0.170 & 0.376 & 1913 & 0.053 & 0.224 & $* * *$ \\
\hline SALES & 2505 & 0.139 & 0.346 & 1913 & 0.013 & 0.114 & $* * *$ \\
\hline UNION & 2535 & 0.824 & 0.381 & 2145 & 0.733 & 0.443 & $* * *$ \\
\hline
\end{tabular}

Sources: Japanese Worker Representation and Participation Survey (JWRPS)

and Korean Worker Representation and Participation Survey (KWRPS)

Notes:

Japan-Korea Difference is based on two-sample test of means.

*Significant at the 10 percent level; **Significant at the 5 percent level; ***Significant at the 1 percent level

AGE=employee's age

MIDCAR $=1$ if the ith employee is a mid-career hire, 0 otherwise.

MALE $=1$ if the ith employee is male, 0 otherwise.

HIGHEDU $=1$ if the ith employee has some college education, 0 otherwise.

NORANK $=1$ if the ith employee has no supervisory responsibilities, 0 otherwise.

$\mathrm{ULBOT}=1$ if the ith employee is a grassroots-level union representative, 0 otherwise.

$B L U E=1$ if the ith employee is working in production as an operator or a maitenance worker, 0 otherwise (omitted as a reference group).

$\mathrm{TECH}=1$ if the ith employee is an engineer or a scientist, 0 otherwise.

$\mathrm{STAFF}=1$ if the ith employee is working in accounting, finance, human resources and other staff functions, 0 otherwise.

SALES $=1$ if the ith employee is working in sales and marketing, 0 otherwise.

$\mathrm{UNION}=1$ if the ith employee is an union member, 0 otherwise. 
Table 2 Differences in Voice between Japan and Korea

\begin{tabular}{|c|c|c|c|c|c|c|c|}
\hline \multirow[b]{2}{*}{ Variable } & \multicolumn{3}{|c|}{ Japan } & \multicolumn{3}{|c|}{ Korea } & \multirow[b]{2}{*}{ Japan-Korea difference } \\
\hline & $\mathrm{N}$ & Mean & Std Dev & $\mathrm{N}$ & Mean & Std Dev & \\
\hline SVOJOB & 2524 & 2.244 & 0.779 & 2084 & 1.536 & 0.769 & $* * *$ \\
\hline SVOGOL & 2519 & 1.060 & 0.953 & 2066 & 1.104 & 0.780 & $*$ \\
\hline SVOTIM & 2517 & 1.205 & 1.084 & 2069 & 1.219 & 0.803 & \\
\hline SVOTRA & 2515 & 1.027 & 0.967 & 2078 & 1.094 & 0.712 & $* * *$ \\
\hline DVOJOB & 2519 & 2.715 & 0.514 & 2053 & 2.181 & 0.698 & $* * *$ \\
\hline DVOGOL & 2511 & 2.194 & 0.695 & 2038 & 1.997 & 0.773 & $* * *$ \\
\hline DVOTIM & 2513 & 2.078 & 0.777 & 2038 & 1.997 & 0.753 & $* * *$ \\
\hline DVOTRA & 2514 & 2.325 & 0.737 & 2047 & 1.982 & 0.731 & $* * *$ \\
\hline PROPOS & 2530 & 1.719 & 0.780 & 2105 & 1.627 & 0.824 & $* * *$ \\
\hline
\end{tabular}

Sources: Japanese Worker Representation and Participation Survey (JWRPS)

and Korean Worker Representation and Participation Survey (KWRPS)

Notes:

Japan-Korea Difference is based on two-sample test of means.

*Significant at the 10 percent level; **Significant at the 5 percent level; ***Significant at the 1 percent level

$\mathrm{SVOJOB}=3$ if the ith employee has a lot of involvement and influence on deciding how to do his/her job and organize the work;

$\mathrm{SVOJOB}=2$ if the ith employee has some involvement and influence on deciding how to do his/her job and organize the work;

$\mathrm{SVOJOB}=1$ if the ith employee has little involvement and influence on deciding how to do his/her job and organize the work;

$\mathrm{SVOJOB}=0$ if the ith employee has no involvement and influence on deciding how to do his/her job and organize the work.

SVOGOL=3 if the ith employee has a lot of involvement and influence on setting goals for his/her work group or department;

$\mathrm{SVOGOL}=2$ if the ith employee has some involvement and influence on setting goals for his/her work group or department;

SVOGOL=1 if the ith employee has little involvement and influence on setting goals for his/her work group or department;

SVOGOL $=0$ if the ith employee has no involvement and influence on setting goals for his/her work group or department.

SVOTIM=3 if the ith employee has a lot of involvement and influence on setting work schedules, including breaks, overtime and time off;

SVOTIM=2 if the ith employee has some involvement and influence on setting work schedules, including breaks, overtime and time off;

SVOTIM=1 if the ith employee has little involvement and influence on setting work schedules, including breaks, overtime and time off;

SVOTIM=0 if the ith employee has no involvement and influence on setting work schedules, including breaks, overtime and time off;

SVOTRA $=3$ if the ith employee has a lot of involvement and influence on deciding what training is needed for people;

SVOTRA $=2$ if the ith employee has some involvement and influence on deciding what training is needed for people;

SVOTRA $=1$ if the ith employee has little involvement and influence on deciding what training is needed for people;

SVOTRA $=0$ if the ith employee has no involvement and influence on deciding what training is needed for people;

$\mathrm{DVOJOB}=3$ if the ith employee considers it very important to has a lot of involvement and influence on deciding how to do his/her job and organize the work;

$\mathrm{DVOJOB}=2$ if the ith employee considers it somewhat important to have a lot of involvement and influence on deciding how to do his/her job and organize the work;

$\mathrm{DVOJOB}=1$ if the ith employee considers it not very important to have a lot of involvement and influence on deciding how to do his/her job and organize the work;

$\mathrm{DVOJOB}=0$ if the ith employee considers it not at all important to have a lot of involvement and influence on deciding how to do his/her job and organize the work.

DVOGOL, DVOTIM, and DVOTRA are defined likewise.

PROPOS=3 if the ith employee often makes suggestions to her boss concerning how to raise productivity and improve quality;

PROPOS=2 if the ith employee sometimes makes suggestions to her boss concerning how to raise productivity and improve quality;

PROPOS=1 if the ith employee rarely makes suggestions to her boss concerning how to raise productivity and improve quality;

PROPOS $=0$ if the ith employee never makes suggestions to her boss concerning how to raise productivity and improve quality; 
Table 3 Differences in the use of HPWPs between Japan and Korea

\begin{tabular}{|c|c|c|c|c|c|c|c|}
\hline \multirow[b]{2}{*}{ Variable } & \multicolumn{3}{|c|}{ Japan } & \multicolumn{3}{|c|}{ Korea } & \multirow[b]{2}{*}{ Japan-Korea difference } \\
\hline & $\mathrm{N}$ & Mean & Std Dev & $\mathrm{N}$ & Mean & Std Dev & \\
\hline SFC & 2530 & 0.595 & 0.491 & 2098 & 0.697 & $\overline{\overline{0.460}}$ & $* * *$ \\
\hline SGA & 2526 & 0.428 & 0.495 & 2088 & 0.837 & 0.370 & $* * *$ \\
\hline JLMC & 2513 & 0.088 & 0.283 & 2129 & 0.074 & 0.262 & *** \\
\hline SFCPART & 1446 & 0.498 & 0.500 & 1442 & 0.197 & 0.398 & $* * *$ \\
\hline SGAPART & 1074 & 0.846 & 0.361 & 1730 & 0.388 & 0.488 & $* * *$ \\
\hline PSP & 2483 & 0.801 & 0.399 & 2145 & 0.657 & 0.475 & $* * *$ \\
\hline
\end{tabular}

Sources: Japanese Worker Representation and Participation Survey (JWRPS)

and Korean Worker Representation and Participation Survey (KWRPS)

Notes:

Japan-Korea Difference is based on two-sample test of means.

*Significant at the 10 percent level; **Significant at the 5 percent level; ***Significant at the 1 percent level

$\mathrm{SFC}=1$ if the ith employee works in a firm with Shopfloor Committees, 0 otherwise.

$\mathrm{SGA}=1$ if the ith employee works in a firm with Small Group Activities, 0 otherwise.

$\mathrm{JLMC}=1$ if the ith employee believes that nearly all information shared in Joint Labor-Management Committees

is made available to him/her, 0 otherwise.

SFCPART $=1$ if the ith employee almost always attends Shopfloor Committee meetings, 0 otherwise.

SGAPART $=1$ if the ith employee participates in Small Group Activities, 0 otherwise.

$\mathrm{PSP}=1$ if the ith employee's compensation includes profit sharing bonus which is linked to firm performance, 0 otherwise. 
Table 4-1 Ordered Probit Estimates on the Effect on Voice of SFC

\begin{tabular}{|c|c|c|c|c|c|c|c|c|c|c|}
\hline \multirow[b]{3}{*}{ Variable } & \multicolumn{5}{|c|}{ Voice on Job } & \multicolumn{5}{|c|}{ Voice on Goal } \\
\hline & \multicolumn{2}{|c|}{ Japan } & \multicolumn{2}{|c|}{ Korea } & \multirow{2}{*}{$\begin{array}{l}\text { Japan vs. } \\
\text { Korea }\end{array}$} & \multicolumn{2}{|c|}{ Japan } & \multicolumn{2}{|c|}{ Korea } & \multirow{2}{*}{\begin{tabular}{|l} 
Japan vs \\
Korea
\end{tabular}} \\
\hline & Coefficient & s.e. & Coefficient & s.e. & & Coefficient & s.e. & Coefficient & s.e. & \\
\hline Constant & 1.188 & $0.176 * * *$ & 2.287 & $0.174 * * *$ & & -0.039 & 0.172 & 1.471 & $0.174 * * *$ & \\
\hline SFC & 0.167 & $0.047 * * *$ & 0.159 & $0.064 * * *$ & & 0.321 & $0.046 * * *$ & 0.245 & $0.065 * * *$ & * \\
\hline AGE & 0.021 & $0.004 * * *$ & -0.018 & $0.004 * * *$ & $* * *$ & 0.012 & $0.003 * * *$ & -0.010 & $0.004 * *$ & $* * *$ \\
\hline MIDCAR & -0.094 & 0.067 & -0.064 & 0.057 & & -0.017 & 0.065 & -0.083 & 0.057 & \\
\hline MALE & 0.267 & $0.065 * * *$ & 0.308 & $0.064 * * *$ & & 0.473 & $0.067 * * *$ & 0.190 & $0.064 * * *$ & \\
\hline HIGHEDU & 0.075 & 0.053 & 0.082 & 0.065 & & 0.014 & 0.052 & 0.141 & $0.065 * *$ & \\
\hline NORANK & -0.440 & $0.055 * * *$ & -0.549 & $0.078 * * *$ & & -0.650 & $0.052 * * *$ & -0.548 & $0.077 * * *$ & \\
\hline ULBOT & 0.100 & $0.052 * *$ & 0.290 & 0.299 & & 0.099 & $0.051 * *$ & 0.813 & $0.296 * * *$ & $* * *$ \\
\hline TECH & 0.062 & 0.063 & -0.154 & $0.061 * * *$ & $* * *$ & -0.123 & $0.061 * *$ & -0.116 & $0.061 * *$ & \\
\hline STAFF & 0.293 & $0.078 * * *$ & 0.044 & 0.131 & $*$ & 0.039 & 0.076 & 0.290 & $0.130 * *$ & $* *$ \\
\hline SALES & 0.338 & $0.080 * * *$ & -0.134 & 0.250 & $* *$ & -0.257 & $0.078 * * *$ & 0.546 & $0.256 * *$ & $* * *$ \\
\hline UNION & -0.081 & 0.076 & -0.048 & 0.066 & & -0.097 & 0.075 & -0.209 & $0.066 * * *$ & \\
\hline $\begin{array}{l}\text { Sample size } \\
\text { Log of the } \\
\text { Likelihood }\end{array}$ & & 2436 & & 1578 & & & 2431 & & 1570 & \\
\hline Function & & 09.261 & & 1718.874 & & & 56.162 & & 10.714 & \\
\hline Model $\chi^{<}$ & & 48.518 & & 121.818 & & & 59.461 & & 74.165 & \\
\hline
\end{tabular}

Sources: Japanese Worker Representation and Participation Survey (JWRPS)

and Korean Worker Representation and Participation Survey (KWRPS)

Notes:

The statistical significance of the difference in the estimated coefficients between Japan and Korea is tested by pooling the Japanese and Korean samples and estimating a benchmark model

augmented by a full set of interation terms involving between each explanatory variable

and Korea dummy (=1 if the ith employee works for a Korean firm, 0 otherwise).

*Significant at the 10 percent level; **Significant at the 5 percent level; ***Significant at the 1 percent level 
Table 4-2 Ordered Probit Estimates on the Effect on Voice of SFC

\begin{tabular}{|c|c|c|c|c|c|c|c|c|c|c|}
\hline \multirow[b]{3}{*}{ Variable } & \multicolumn{5}{|c|}{ Voice on Schedule } & \multicolumn{5}{|c|}{ Voice on Training } \\
\hline & \multicolumn{2}{|r|}{ Japan } & \multicolumn{2}{|r|}{ Korea } & \multirow{2}{*}{$\begin{array}{l}\text { Japan vs. } \\
\text { Korea }\end{array}$} & \multicolumn{2}{|r|}{ Japan } & \multicolumn{2}{|r|}{ Korea } & \multirow{2}{*}{\begin{tabular}{|l} 
Japan vs. \\
Korea \\
\end{tabular}} \\
\hline & Coefficient & s.e. & Coefficient & s.e. & & Coefficient & s.e. & Coefficient & s.e. & \\
\hline Constant & 0.508 & $0.169 * * *$ & 1.273 & $0.171 * * *$ & & 0.199 & 0.171 & 1.715 & $0.176 * * *$ & \\
\hline SFC & 0.243 & $0.046 * * *$ & 0.248 & $0.064 * * *$ & & 0.347 & $0.047 * * *$ & 0.204 & $0.066 * * *$ & $* * *$ \\
\hline AGE & -0.007 & $0.003 * *$ & -0.003 & 0.004 & & 0.005 & 0.003 & -0.011 & $0.004 * * *$ & $* * *$ \\
\hline MIDCAR & -0.022 & 0.065 & -0.094 & $0.057 *$ & & -0.034 & 0.065 & -0.052 & 0.058 & \\
\hline MALE & 0.164 & $0.065 * * *$ & 0.016 & 0.063 & $*$ & 0.395 & $0.067 * * *$ & 0.014 & 0.065 & $* * *$ \\
\hline HIGHEDU & 0.122 & $0.052 * *$ & 0.186 & $0.065 * * *$ & & 0.021 & 0.052 & 0.186 & $0.066 * * *$ & \\
\hline NORANK & -0.402 & $0.051 * * *$ & -0.465 & $0.077 * * *$ & & -0.674 & $0.052 * * *$ & -0.616 & $0.078 * * *$ & $* * *$ \\
\hline ULBOT & 0.074 & 0.050 & 0.401 & 0.294 & & -0.019 & 0.051 & 0.818 & $0.289 * * *$ & $*$ \\
\hline TECH & -0.077 & 0.061 & -0.120 & $0.061 * *$ & & -0.148 & $0.062 * * *$ & -0.083 & 0.062 & \\
\hline STAFF & 0.048 & 0.075 & 0.190 & 0.130 & & 0.100 & 0.076 & 0.281 & $0.132 * *$ & \\
\hline SALES & -0.085 & 0.076 & 0.208 & 0.256 & & 0.102 & 0.076 & -0.226 & 0.255 & \\
\hline UNION & 0.094 & 0.074 & -0.052 & 0.066 & & -0.113 & 0.074 & -0.126 & $0.067 *$ & \\
\hline $\begin{array}{l}\text { Sample size } \\
\text { Log of the } \\
\text { Likelihood }\end{array}$ & & 2428 & & 1571 & & & 2427 & & 1576 & \\
\hline Function & & 195.528 & & 1789.688 & & & 893.081 & & 1591.026 & \\
\hline Model $\chi^{2}$ & & 139.206 & & 107.696 & & & 397.188 & & 148.845 & \\
\hline
\end{tabular}

Sources: Japanese Worker Representation and Participation Survey (JWRPS)

and Korean Worker Representation and Participation Survey (KWRPS)

Notes:

The statistical significance of the difference in the estimated coefficients between Japan and Korea is tested by pooling the Japanese and Korean samples and estimating a benchmark model

augmented by a full set of interation terms involving between each explanatory variable

and Korea dummy (=1 if the ith employee works for a Korean firm, 0 otherwise).

*Significant at the 10 percent level; **Significant at the 5 percent level; ***Significant at the 1 percent level 
Table 4-3 Possible interplay between SFC and UNION

\begin{tabular}{|c|c|c|c|c|c|c|c|c|}
\hline \multirow[b]{3}{*}{ Variable } & \multicolumn{4}{|c|}{ Voice on Job } & \multicolumn{4}{|c|}{ Voice on Goal } \\
\hline & \multicolumn{2}{|c|}{ Japan } & \multicolumn{2}{|c|}{ Korea } & \multicolumn{2}{|c|}{ Japan } & \multicolumn{2}{|c|}{ Korea } \\
\hline & Coefficient & s.e. & Coefficient & s.e. & Coefficient & s.e. & Coefficient & s.e. \\
\hline SFC & 0.164 & 0.110 & 0.352 & $0.154 * *$ & 0.383 & $0.108 * * *$ & $\overline{0.321}$ & $0.152 * *$ \\
\hline UNION & -0.083 & 0.101 & 0.150 & 0.158 & -0.054 & 0.102 & -0.131 & 0.157 \\
\hline UNION*SFC & 0.004 & 0.121 & -0.233 & 0.169 & -0.075 & 0.120 & -0.092 & 0.169 \\
\hline \multirow[b]{3}{*}{ Variable } & \multicolumn{4}{|c|}{ Voice on Schedule } & \multicolumn{4}{|c|}{ Voice on Training } \\
\hline & \multicolumn{2}{|c|}{ Japan } & \multicolumn{2}{|c|}{ Korea } & \multicolumn{2}{|c|}{ Japan } & \multicolumn{2}{|c|}{ Korea } \\
\hline & Coefficient & s.e. & Coefficient & s.e. & Coefficient & s.e. & Coefficient & s.e. \\
\hline SFC & 0.290 & $0.107 * * *$ & 0.203 & 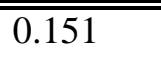 & 0.322 & $0.107 * * *$ & "0.548 & $0.156 * * *$ \\
\hline UNION & 0.127 & 0.100 & -0.098 & 0.156 & -0.131 & 0.101 & 0.229 & 0.161 \\
\hline UNION*SFC & -0.057 & 0.118 & 0.055 & 0.167 & 0.031 & 0.119 & -0.419 & $0.172 * *$ \\
\hline
\end{tabular}

Sources: Japanese Worker Representation and Participation Survey (JWRPS)

and Korean Worker Representation and Participation Survey (KWRPS)

Notes:

Based on the ordered probit estimations of Eqs. (1)-(4), augmented by an interaction term involving UNION and SFC.

*Significant at the 10 percent level; **Significant at the 5 percent level; ***Significant at the 1 percent level 
Table 5-1 Ordered Probit Estimates on the Effect on Voice of SGA

\begin{tabular}{|c|c|c|c|c|c|c|c|c|c|c|}
\hline \multirow[b]{3}{*}{ Variable } & \multicolumn{5}{|c|}{ Voice on Job } & \multicolumn{5}{|c|}{ Voice on Goal } \\
\hline & \multicolumn{2}{|c|}{ Japan } & \multicolumn{2}{|c|}{ Korea } & \multirow{2}{*}{$\begin{array}{l}\text { Japan vs. } \\
\text { Korea }\end{array}$} & \multicolumn{2}{|c|}{ Japan } & \multicolumn{2}{|c|}{ Korea } & \multirow{2}{*}{\begin{tabular}{|l} 
Japan vs. \\
Korea \\
\end{tabular}} \\
\hline & Coefficient & s.e. & Coefficient & s.e. & & Coefficient & s.e. & Coefficient & s.e. & \\
\hline Constant & 1.183 & $0.176 * * *$ & 2.353 & $0.168 * * *$ & & -0.049 & 0.172 & 1.605 & $0.168 * * *$ & \\
\hline SGA & 0.168 & $0.047 * * *$ & 0.154 & $0.083 *$ & & 0.276 & $0.046 * * *$ & 0.239 & $0.084 * * *$ & \\
\hline AGE & 0.022 & $0.004 * * *$ & -0.018 & $0.004 * * *$ & $* * *$ & 0.013 & $0.003 * * *$ & -0.012 & $0.004 * * *$ & $* * *$ \\
\hline MIDCAR & -0.100 & 0.067 & -0.064 & 0.057 & & -0.027 & 0.066 & -0.065 & 0.058 & \\
\hline MALE & 0.265 & $0.065 * * *$ & 0.324 & $0.064 * * *$ & & 0.470 & $0.067 * * *$ & 0.209 & $0.064 * * *$ & $* * *$ \\
\hline HIGHEDU & 0.083 & 0.054 & 0.093 & 0.065 & & 0.027 & 0.052 & 0.156 & $0.065 * *$ & \\
\hline NORANK & -0.454 & $0.055 * * *$ & -0.565 & $0.078 * * *$ & & -0.673 & $0.052 * * *$ & -0.563 & $0.077 * * *$ & $* * *$ \\
\hline ULBOT & 0.100 & $0.052 *$ & 0.267 & 0.299 & & 0.102 & $0.051 * *$ & 0.795 & $0.296 * * *$ & $* *$ \\
\hline TECH & 0.071 & 0.063 & -0.171 & $0.061 * * *$ & $* * *$ & -0.100 & $0.061 *$ & -0.134 & $0.061 * *$ & \\
\hline STAFF & 0.324 & $0.079 * * *$ & 0.061 & 0.134 & $* *$ & 0.102 & 0.076 & 0.274 & $0.132 * *$ & \\
\hline SALES & 0.353 & $0.080 * * *$ & -0.166 & 0.250 & $* *$ & -0.224 & $0.078 * * *$ & 0.487 & $0.256 *$ & $* * *$ \\
\hline UNION & -0.071 & 0.076 & -0.128 & $0.071 *$ & & -0.071 & 0.075 & -0.355 & $0.071 * * *$ & $* *$ \\
\hline $\begin{array}{l}\text { Sample size } \\
\text { Log of the } \\
\text { Likelihood }\end{array}$ & & 2433 & & 1574 & & & 2428 & & 1566 & \\
\hline Function & & 06.165 & & 713.474 & & & 58.006 & & 11.661 & \\
\hline Model $\chi^{<}$ & & 49.551 & & 24.559 & & & 48.723 & & 71.207 & \\
\hline
\end{tabular}

Sources: Japanese Worker Representation and Participation Survey (JWRPS)

and Korean Worker Representation and Participation Survey (KWRPS)

Notes:

The statistical significance of the difference in the estimated coefficients between Japan and Korea is tested by pooling the Japanese and Korean samples and estimating a benchmark model

augmented by a full set of interation terms involving between each explanatory variable

and Korea dummy (=1 if the ith employee works for a Korean firm, 0 otherwise).

*Significant at the 10 percent level; **Significant at the 5 percent level; ***Significant at the 1 percent level 
Table 5-2 Ordered Probit Estimates on the Effect on Voice of SGA

\begin{tabular}{|c|c|c|c|c|c|c|c|c|c|c|}
\hline \multirow[b]{3}{*}{ Variable } & \multicolumn{5}{|c|}{ Voice on Schedule } & \multicolumn{5}{|c|}{ Voice on Training } \\
\hline & \multicolumn{2}{|c|}{ Japan } & \multicolumn{2}{|c|}{ Korea } & \multirow{2}{*}{$\begin{array}{l}\text { Japan vs. } \\
\text { Korea }\end{array}$} & \multicolumn{2}{|c|}{ Japan } & \multicolumn{2}{|c|}{ Korea } & \multirow{2}{*}{\begin{tabular}{|l} 
Japan vs \\
Korea
\end{tabular}} \\
\hline & Coefficient & s.e. & Coefficient & s.e. & & Coefficient & s.e. & Coefficient & s.e. & \\
\hline Constant & 0.480 & $0.170 * * *$ & 1.377 & $0.165 * * *$ & & 0.204 & 0.171 & 1.848 & $0.170 * * *$ & \\
\hline SGA & 0.270 & $0.045 * * *$ & 0.291 & $0.083 * * *$ & & 0.274 & $0.046 * * *$ & 0.141 & $0.085 *$ & $* *$ \\
\hline AGE & -0.007 & $0.003 * *$ & -0.005 & 0.004 & & 0.006 & $0.003 *$ & -0.012 & $0.004 * * *$ & $* * *$ \\
\hline MIDCAR & -0.032 & 0.065 & -0.095 & $0.057 *$ & & -0.044 & 0.066 & -0.051 & 0.058 & \\
\hline MALE & 0.157 & $0.065 * *$ & 0.025 & 0.063 & & 0.395 & $0.067 * * *$ & 0.020 & 0.065 & $* * *$ \\
\hline HIGHEDU & 0.135 & $0.052 * * *$ & 0.194 & $0.065 * * *$ & & 0.030 & 0.052 & 0.195 & $0.066 * * *$ & \\
\hline NORANK & -0.421 & $0.051 * * *$ & -0.465 & $0.076 * * *$ & & -0.695 & $0.052 * * *$ & -0.626 & $0.078 * * *$ & $* * *$ \\
\hline ULBOT & 0.069 & 0.050 & 0.384 & 0.294 & & -0.019 & 0.051 & 0.777 & $0.288 * * *$ & $* *$ \\
\hline TECH & -0.059 & 0.061 & -0.136 & $0.061 * *$ & & -0.125 & $0.062 * *$ & -0.108 & $0.062 *$ & \\
\hline STAFF & 0.099 & 0.075 & 0.219 & $0.132 *$ & & 0.168 & $0.076 * *$ & 0.268 & $0.134 * *$ & \\
\hline SALES & -0.054 & 0.076 & 0.148 & 0.256 & & 0.134 & $0.077 *$ & -0.274 & 0.255 & \\
\hline UNION & 0.117 & 0.074 & -0.204 & $0.071^{* * *}$ & $* * *$ & -0.086 & 0.074 & -0.226 & $0.072 * * *$ & \\
\hline $\begin{array}{l}\text { Sample size } \\
\text { Log of the } \\
\text { Likelihood }\end{array}$ & & 2425 & & 1567 & & & 2424 & & 1572 & \\
\hline Function & & 3187.209 & & 94.347 & & & 97.899 & & 96.175 & \\
\hline Model $\chi^{<}$ & & 147.083 & & 03.212 & & & 80.036 & & 42.936 & \\
\hline
\end{tabular}

Sources: Japanese Worker Representation and Participation Survey (JWRPS)

and Korean Worker Representation and Participation Survey (KWRPS)

Notes:

The statistical significance of the difference in the estimated coefficients between Japan and Korea is tested by pooling the Japanese and Korean samples and estimating a benchmark model

augmented by a full set of interation terms involving between each explanatory variable

and Korea dummy (=1 if the ith employee works for a Korean firm, 0 otherwise).

*Significant at the 10 percent level; **Significant at the 5 percent level; ***Significant at the 1 percent level 
Table 5-3 Accounting for a Possible Selection Issue with Small Group Activities

\begin{tabular}{|c|c|c|c|c|c|c|c|c|}
\hline \multirow[b]{3}{*}{ Variable } & \multicolumn{5}{|c|}{ Voice on Job } & \multicolumn{3}{|c|}{ Joice on Goal } \\
\hline & \multicolumn{2}{|c|}{ Japan } & \multicolumn{2}{|c|}{ Korea } & \multicolumn{2}{|c|}{ Japan } & \multicolumn{2}{|c|}{ Korea } \\
\hline & Coefficient & s.e. & Coefficient & s.e. & Coefficient & s.e. & Coefficient & s.e. \\
\hline SGAALL & 0.133 & $0.053 * * *$ & 0.169 & $0.090 *$ & 0.273 & $0.053 * * *$ & 0.203 & $0.090 * *$ \\
\hline \multirow[b]{3}{*}{ Variable } & \multicolumn{4}{|c|}{ Voice on Job } & \multirow{2}{*}{\multicolumn{2}{|c|}{$\begin{array}{l}\text { Voice on Goal } \\
\text { Japan }\end{array}$}} & & \\
\hline & \multicolumn{2}{|c|}{ Japan } & \multicolumn{2}{|c|}{ Korea } & & & \multicolumn{2}{|c|}{ Korea } \\
\hline & Coefficient & s.e. & Coefficient & s.e. & Confficiont & s.e. & Coefficient & s.e. \\
\hline SGAALL & 0.273 & $0.052 * * *$ & 0.272 & $0.089 * * *$ & 0.345 & $0.053 * * *$ & 0.096 & 0.091 \\
\hline
\end{tabular}

Sources: Japanese Worker Representation and Participation Survey (JWRPS)

and Korean Worker Representation and Participation Survey (KWRPS)

Notes:

SGAALL=1 if the ith employee works in a firm that has Small Group Activities currently or used to have Small Group Activities, 0 otherwise. Based on the ordered probit estimations of Eqs. (1)-(4) with SGAALL used as an alternative to SGA.

*Significant at the 10 percent level; **Significant at the 5 percent level; ***Significant at the 1 percent level 
Table 5-4 Possible interplay between SGA and UNION

\begin{tabular}{|c|c|c|c|c|c|c|c|c|}
\hline \multirow[b]{3}{*}{ Variable } & \multicolumn{4}{|c|}{ Voice on Job } & \multicolumn{4}{|c|}{ Voice on Goal } \\
\hline & \multicolumn{2}{|c|}{ Japan } & \multicolumn{2}{|c|}{ Korea } & \multicolumn{2}{|c|}{ Japan } & \multicolumn{2}{|c|}{ Korea } \\
\hline & \begin{tabular}{|l} 
Coefficient \\
\end{tabular} & s.e. & Coefficient & s.e. & Coefficient & s.e. & Coefficient & s.e. \\
\hline SGA & 0.228 & $0.113 * *$ & 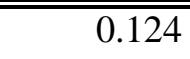 & 0.102 & 0.352 & $0.109 * * *$ & 0.126 & 0.102 \\
\hline UNION & -0.042 & 0.090 & -0.201 & 0.158 & -0.032 & 0.091 & -0.637 & $0.162 * * *$ \\
\hline \multirow[t]{3}{*}{ UNION*SGA } & -0.073 & 0.124 & 0.090 & 0.174 & -0.092 & 0.120 & 0.344 & 0.178 \\
\hline & \multicolumn{4}{|c|}{ Voice on Schedule } & \multicolumn{4}{|c|}{ Voice on Training } \\
\hline & \multicolumn{2}{|c|}{ Japan } & \multicolumn{2}{|c|}{ Korea } & \multicolumn{2}{|c|}{ Japan } & \multicolumn{2}{|c|}{ Korea } \\
\hline Variable & Coefficient & s.e. & Coefficient & s.e. & Coefficient & s.e. & Coefficient & s.e. \\
\hline SGA & 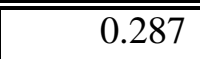 & $0.108 * * *$ & 0.216 & $0.101 * *$ & 0.338 & $0.108 * * *$ & 0.024 & 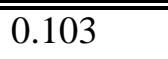 \\
\hline UNION & 0.125 & 0.089 & -0.389 & $0.160 * *$ & -0.053 & 0.089 & -0.518 & $0.163 * * *$ \\
\hline UNION*SGA & -0.020 & 0.119 & 0.226 & 0.175 & -0.077 & 0.119 & 0.357 & $0.179 * *$ \\
\hline
\end{tabular}

Sources: Japanese Worker Representation and Participation Survey (JWRPS)

and Korean Worker Representation and Participation Survey (KWRPS)

Notes:

Based on the ordered probit estimations of Eqs. (1)-(4), augmented by an interaction term involving UNION and SGA.

*Significant at the 10 percent level; **Significant at the 5 percent level; ***Significant at the 1 percent level 
Table 6-1 Ordered Probit Estimates on the Effect on Voice of JLMC

\begin{tabular}{|c|c|c|c|c|c|c|c|c|c|c|}
\hline \multirow[b]{3}{*}{ Variable } & \multicolumn{5}{|c|}{ "Voice on Job } & \multicolumn{5}{|c|}{ "Voice on Goal } \\
\hline & \multicolumn{2}{|r|}{ Japan } & \multicolumn{2}{|r|}{ Korea } & \multirow{2}{*}{\begin{tabular}{|l} 
Japan vs. \\
Korea \\
\end{tabular}} & \multicolumn{2}{|r|}{ Japan } & \multicolumn{2}{|r|}{ Korea } & \multirow{2}{*}{\begin{tabular}{|l} 
Japan vs. \\
Korea
\end{tabular}} \\
\hline & Coefficient & s.e. & Coefficient & s.e. & & Coefficient & s.e. & Coefficient & s.e. & \\
\hline Constant & 1.249 & $0.175 * * *$ & 2.426 & $0.163 * * *$ & & 0.052 & "0.171 & 1.722 & $0.163 * * *$ & \\
\hline JLMC & 0.328 & $0.086 * * *$ & 0.223 & $0.108 * *$ & & 0.057 & 0.079 & 0.273 & $0.108 * * *$ & \\
\hline AGE & 0.021 & $0.004 * * *$ & -0.018 & $0.004 * * *$ & $* * *$ & 0.013 & $0.003 * * *$ & -0.012 & $0.004 * * *$ & $* * *$ \\
\hline MIDCAR & -0.084 & 0.067 & -0.070 & 0.057 & & -0.014 & 0.066 & -0.073 & 0.057 & \\
\hline MALE & 0.262 & $0.066 * * *$ & 0.291 & $0.064 * * *$ & & 0.479 & $0.067 * * *$ & 0.178 & $0.064 * * *$ & $* * *$ \\
\hline HIGHEDU & 0.080 & 0.054 & 0.097 & 0.065 & & 0.023 & 0.052 & 0.166 & $0.065 * * *$ & \\
\hline NORANK & -0.456 & $0.055 * * *$ & -0.538 & $0.077 * * *$ & & -0.658 & $0.052 * * *$ & -0.551 & $0.077 * * *$ & $* * *$ \\
\hline ULBOT & 0.114 & $0.052 * *$ & 0.265 & 0.298 & & 0.121 & $0.051 * *$ & 0.765 & $0.296 * * *$ & $*$ \\
\hline TECH & 0.072 & 0.063 & -0.166 & $0.060 * * *$ & $* * *$ & -0.115 & $0.061 *$ & -0.127 & $0.061 * *$ & \\
\hline STAFF & 0.289 & $0.079 * * *$ & 0.050 & 0.131 & $*$ & 0.068 & 0.076 & 0.289 & $0.130 * *$ & \\
\hline SALES & 0.342 & $0.080 * * *$ & -0.142 & 0.250 & $* *$ & -0.269 & $0.078 * * *$ & 0.511 & $0.256 * *$ & $* * *$ \\
\hline UNION & -0.073 & 0.077 & -0.096 & 0.065 & & -0.070 & 0.075 & -0.280 & $0.065 * * *$ & $*$ \\
\hline $\begin{array}{l}\text { Sample size } \\
\text { Log of the } \\
\text { Likelihood }\end{array}$ & & 2421 & & 1587 & & & 2416 & & 1579 & \\
\hline Function & & -2495.143 & & -1732.337 & & & -2860.838 & & -1727.289 & \\
\hline Model $\chi^{2}$ & & 250.929 & & 119.138 & & & 408.315 & & 170.109 & \\
\hline
\end{tabular}

Sources: Japanese Worker Representation and Participation Survey (JWRPS)

and Korean Worker Representation and Participation Survey (KWRPS)

Notes:

The statistical significance of the difference in the estimated coefficients between Japan and Korea is tested by

pooling the Japanese and Korean samples and estimating a benchmark model

augmented by a full set of interation terms involving between each explanatory variable

and Korea dummy (=1 if the ith employee works for a Korean firm, 0 otherwise).

*Significant at the 10 percent level; **Significant at the 5 percent level; ***Significant at the 1 percent level 
Table 6-2 Ordered Probit Estimates on the Effect on Voice of JLMC

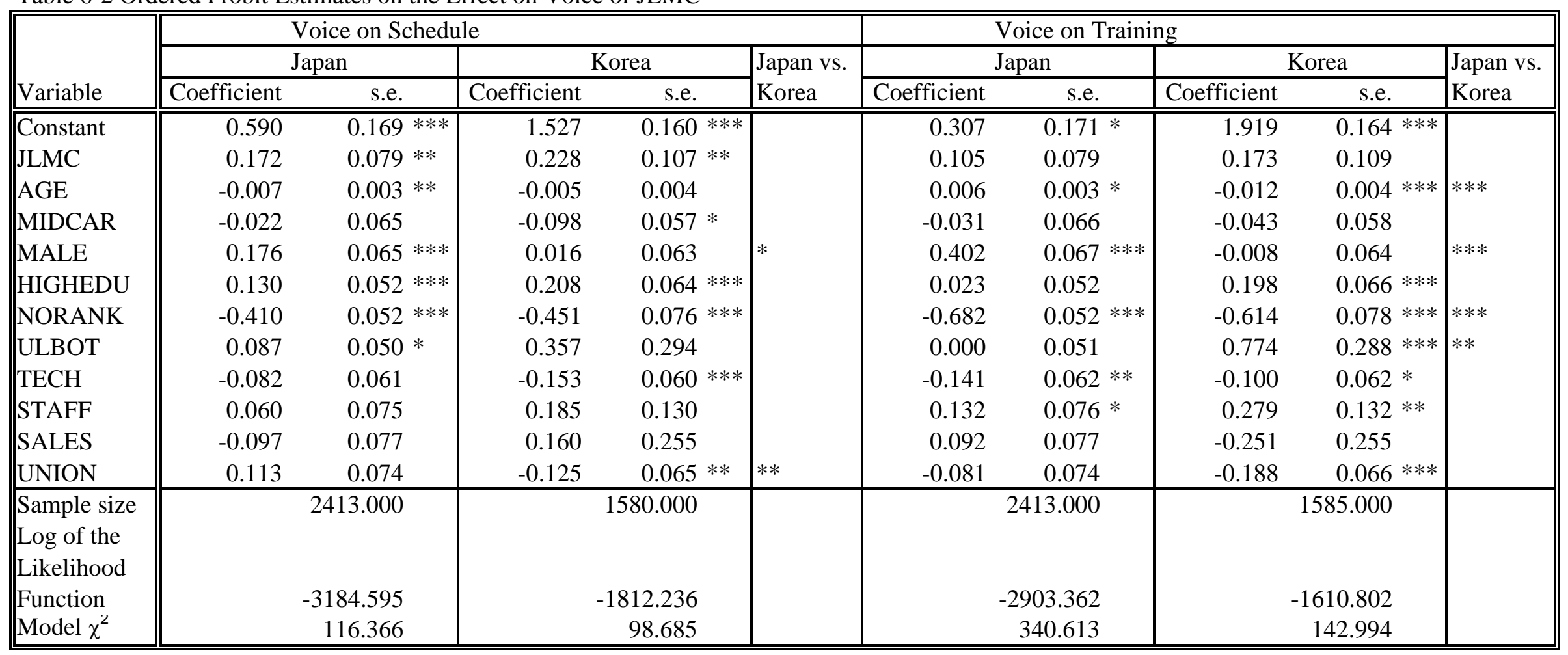

Sources: Japanese Worker Representation and Participation Survey (JWRPS)

and Korean Worker Representation and Participation Survey (KWRPS)

Notes:

The statistical significance of the difference in the estimated coefficients between Japan and Korea is tested by pooling the Japanese and Korean samples and estimating a benchmark model

augmented by a full set of interation terms involving between each explanatory variable

and Korea dummy (=1 if the ith employee works for a Korean firm, 0 otherwise).

*Significant at the 10 percent level; **Significant at the 5 percent level; ***Significant at the 1 percent level 
Table 6-3 Possible interplay between JLMC and UNION

\begin{tabular}{|c|c|c|c|c|c|c|c|c|}
\hline \multirow[b]{3}{*}{ Variable } & \multicolumn{4}{|c|}{ Voice on Job } & \multicolumn{4}{|c|}{ Voice on Goal } \\
\hline & \multicolumn{2}{|c|}{ Japan } & \multicolumn{2}{|c|}{ Korea } & \multicolumn{2}{|c|}{ Japan } & \multicolumn{2}{|c|}{ Korea } \\
\hline & \begin{tabular}{|l|} 
Coefficient \\
\end{tabular} & s.e. & Coefficient & s.e. & Coefficient & s.e. & Coefficient & s.e. \\
\hline JLMC & 0.195 & 0.210 & -0.037 & 0.309 & 0.346 & $0.189 * *$ & 0.467 & 0.307 \\
\hline UNION & -0.082 & 0.078 & -0.106 & 0.066 & -0.045 & 0.076 & -0.272 & $0.066 * * *$ \\
\hline \multirow[t]{3}{*}{ UNION*JLMC } & 0.159 & 0.230 & 0.295 & 0.329 & -0.350 & $0.208 *$ & -0.220 & 0.327 \\
\hline & \multicolumn{4}{|c|}{ Voice on Schedule } & \multicolumn{4}{|c|}{ Voice on Training } \\
\hline & \multicolumn{2}{|c|}{ Japan } & \multicolumn{2}{|c|}{ Korea } & \multicolumn{2}{|c|}{ Japan } & \multicolumn{2}{|c|}{ Korea } \\
\hline Variable & Coefficient & s.e. & Coefficient & s.e. & Coefficient & s.e. & Coefficient & s.e. \\
\hline JLMC & 0.539 & $0.186 * * *$ & 0.291 & 0.304 & 0.252 & 0.187 & -0.108 & 0.312 \\
\hline UNION & 0.145 & $0.076 *$ & -0.123 & $0.065 *$ & -0.069 & 0.076 & -0.199 & $0.067 * * *$ \\
\hline UNION*JLMC & -0.446 & $0.205 * *$ & -0.072 & 0.324 & -0.178 & 0.206 & 0.320 & 0.332 \\
\hline
\end{tabular}

Sources: Japanese Worker Representation and Participation Survey (JWRPS)

and Korean Worker Representation and Participation Survey (KWRPS)

Notes:

Based on the ordered probit estimations of Eqs. (1)-(4), augmented by an interaction term involving UNION and JLMC.

*Significant at the 10 percent level; **Significant at the 5 percent level; ***Significant at the 1 percent level 
Table 7-1 Ordered Probit Estimates on the Effect on Voice of SFC, SGA and JLMC

\begin{tabular}{|c|c|c|c|c|c|c|c|c|c|c|}
\hline \multirow[b]{3}{*}{ Variable } & \multicolumn{5}{|c|}{ Voice on Job } & \multicolumn{5}{|c|}{ Voice on Goal } \\
\hline & \multicolumn{2}{|c|}{ Japan } & \multicolumn{2}{|c|}{ Korea } & \multirow{2}{*}{$\begin{array}{l}\text { Japan vs. } \\
\text { Korea }\end{array}$} & \multicolumn{2}{|c|}{ Japan } & \multicolumn{2}{|c|}{ Korea } & \multirow{2}{*}{\begin{tabular}{|l} 
Japan vs \\
Korea
\end{tabular}} \\
\hline & Coefficient & s.e. & Coefficient & s.e. & & Coefficient & s.e. & Coefficient & s.e. & \\
\hline Constant & 1.140 & $0.177 * * *$ & 2.247 & $0.177 * * *$ & & "-0.167 & 0.174 & "1.407 & 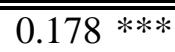 & \\
\hline SFC & 0.132 & $0.048 * * *$ & 0.152 & $0.067 * *$ & & 0.287 & $0.047 * * *$ & 0.227 & $0.068 * * *$ & \\
\hline SGA & 0.138 & $0.048 * * *$ & 0.103 & 0.086 & & 0.226 & $0.047 * * *$ & 0.180 & $0.087 * *$ & \\
\hline JLMC & 0.301 & $0.086 * * *$ & 0.203 & $0.109 *$ & & 0.004 & 0.080 & 0.269 & $0.109 * * *$ & * \\
\hline AGE & 0.021 & $0.004 * * *$ & -0.018 & $0.004 * * *$ & $* * *$ & 0.012 & $0.003 * * *$ & -0.011 & $0.004 * * *$ & $* * *$ \\
\hline MIDCAR & -0.093 & 0.068 & -0.057 & 0.058 & & -0.015 & 0.066 & -0.072 & 0.058 & \\
\hline MALE & 0.261 & $0.066 * * *$ & 0.311 & $0.064 * * *$ & & 0.474 & $0.068 * * *$ & 0.207 & $0.065 * * *$ & $* * *$ \\
\hline HIGHEDU & 0.080 & 0.054 & 0.086 & 0.066 & & 0.026 & 0.053 & 0.147 & $0.066 * *$ & \\
\hline NORANK & -0.451 & $0.055 * * *$ & -0.570 & $0.078 * * *$ & & -0.656 & $0.052 * * *$ & -0.556 & $0.078 * * *$ & $* * *$ \\
\hline ULBOT & 0.090 & $0.053 *$ & 0.281 & 0.299 & & 0.083 & $0.051 *$ & 0.815 & $0.297 * * *$ & $* *$ \\
\hline TECH & 0.077 & 0.063 & -0.145 & $0.062 * *$ & $* * *$ & -0.104 & $0.062 *$ & -0.114 & $0.062 *$ & \\
\hline STAFF & 0.294 & $0.079 * * *$ & 0.055 & 0.134 & * & 0.073 & 0.077 & 0.268 & $0.133 * *$ & \\
\hline SALES & 0.362 & $0.081 * * *$ & -0.122 & 0.250 & $* *$ & -0.241 & $0.078 * * *$ & 0.555 & $0.257 * *$ & $* * *$ \\
\hline UNION & -0.078 & 0.077 & -0.089 & 0.075 & & -0.075 & 0.075 & -0.295 & $0.075 * * *$ & * \\
\hline $\begin{array}{l}\text { Sample size } \\
\text { Log of the } \\
\text { Likelihood }\end{array}$ & & 2418 & & 1554 & & & 2413 & & 1546 & \\
\hline Function & & 79.640 & & 91.653 & & & 20.986 & & 78.161 & \\
\hline Model $\chi^{<}$ & & 71.194 & & 30.886 & & & 81.324 & & 86.468 & \\
\hline
\end{tabular}

Sources: Japanese Worker Representation and Participation Survey (JWRPS)

and Korean Worker Representation and Participation Survey (KWRPS)

Notes:

The statistical significance of the difference in the estimated coefficients between Japan and Korea is tested by pooling the Japanese and Korean samples and estimating a benchmark model

augmented by a full set of interation terms involving between each explanatory variable

and Korea dummy (=1 if the ith employee works for a Korean firm, 0 otherwise).

*Significant at the 10 percent level; **Significant at the 5 percent level; ***Significant at the 1 percent level 
Table 7-2 Ordered Probit Estimates on the Effect on Voice of SFC, SGA and JLMC

\begin{tabular}{|c|c|c|c|c|c|c|c|c|c|c|}
\hline \multirow[b]{3}{*}{ Variable } & \multicolumn{5}{|c|}{ "Voice on Schedule } & \multicolumn{5}{|c|}{ Voice on Training } \\
\hline & \multicolumn{2}{|c|}{ Japan } & \multicolumn{2}{|c|}{ Korea } & \multirow{2}{*}{$\begin{array}{l}\text { Japan vs. } \\
\text { Korea }\end{array}$} & \multicolumn{2}{|c|}{ Japan } & \multicolumn{2}{|c|}{ Korea } & \multirow{2}{*}{$\begin{array}{l}\text { Japan vs } \\
\text { Korea }\end{array}$} \\
\hline & Coefficient & s.e. & Coefficient & s.e. & & Coefficient & s.e. & Coefficient & s.e. & \\
\hline Constant & 0.411 & $0.171 * *$ & 1.230 & $0.174 * * *$ & & 0.094 & 0.173 & 1.692 & $0.180 * * *$ & \\
\hline SFC & 0.203 & $0.047 * * *$ & 0.197 & $0.067 * * *$ & & 0.310 & $0.048 * * *$ & 0.204 & $0.068 * * *$ & $* *$ \\
\hline SGA & 0.231 & $0.046 * * *$ & 0.227 & $0.086 * * *$ & & 0.220 & $0.047 * * *$ & 0.081 & 0.088 & * \\
\hline JLMC & 0.131 & $0.079 *$ & 0.189 & $0.108 *$ & & 0.055 & 0.080 & 0.161 & 0.111 & \\
\hline AGE & -0.008 & $0.003 * *$ & -0.005 & 0.004 & & 0.005 & 0.003 & -0.012 & $0.005 * * *$ & $* * *$ \\
\hline MIDCAR & -0.028 & 0.065 & -0.092 & $0.058 *$ & & -0.034 & 0.066 & -0.041 & 0.059 & \\
\hline MALE & 0.165 & $0.066 * * *$ & 0.017 & 0.064 & & 0.395 & $0.068 * * *$ & 0.021 & 0.065 & $* * *$ \\
\hline HIGHEDU & 0.136 & $0.052 * * *$ & 0.191 & $0.065 * * *$ & & 0.024 & 0.053 & 0.187 & $0.066 * * *$ & \\
\hline NORANK & -0.408 & $0.052 * * *$ & -0.470 & $0.077 * * *$ & & -0.682 & $0.052 * * *$ & -0.626 & $0.079 * * *$ & $* * *$ \\
\hline ULBOT & 0.053 & 0.051 & 0.410 & 0.295 & & -0.041 & 0.051 & 0.820 & $0.289 * * *$ & $* *$ \\
\hline TECH & -0.070 & 0.061 & -0.108 & $0.061 *$ & & -0.131 & $0.062 * *$ & -0.089 & 0.063 & \\
\hline STAFF & 0.071 & 0.076 & 0.218 & $0.132 *$ & & 0.136 & $0.077 *$ & 0.269 & $0.134 * *$ & \\
\hline SALES & -0.064 & 0.077 & 0.213 & 0.256 & & 0.129 & $0.077 *$ & -0.222 & 0.255 & \\
\hline UNION & 0.115 & 0.074 & -0.146 & $0.075 * *$ & $* *$ & -0.088 & 0.075 & -0.169 & $0.076 * *$ & \\
\hline $\begin{array}{l}\text { Sample size } \\
\text { Log of the } \\
\text { Likelihood }\end{array}$ & & 2410 & & 1547 & & & 2410 & & 1552 & \\
\hline Function & & 53.909 & & 60.518 & & & 360.781 & & 65.548 & \\
\hline Model $\chi^{2}$ & & 69.802 & & 15.604 & & & 19.042 & & 53.275 & \\
\hline
\end{tabular}

Sources: Japanese Worker Representation and Participation Survey (JWRPS) and Korean Worker Representation and Participation Survey (KWRPS)

Notes:

The statistical significance of the difference in the estimated coefficients between Japan and Korea is tested by pooling the Japanese and Korean samples and estimating a benchmark model augmented by a full set of interation terms involving between each explanatory variable and Korea dummy (=1 if the ith employee works for a Korean firm, 0 otherwise).

*Significant at the 10 percent level; **Significant at the 5 percent level; ***Significant at the 1 percent level 
Table 8-1 Ordered Probit Estimates on the Effect on Voice of SFCPART

\begin{tabular}{|c|c|c|c|c|c|c|c|c|c|c|}
\hline \multirow[b]{3}{*}{ Variable } & \multicolumn{5}{|c|}{ Voice on Job } & \multicolumn{5}{|c|}{ Voice on Goal } \\
\hline & \multicolumn{2}{|c|}{ Japan } & \multicolumn{2}{|c|}{ Korea } & \multirow{2}{*}{$\begin{array}{l}\text { Japan vs. } \\
\text { Korea }\end{array}$} & \multicolumn{2}{|c|}{ Japan } & \multicolumn{2}{|c|}{ Korea } & \multirow{2}{*}{$\begin{array}{l}\text { Japan vs } \\
\text { Korea }\end{array}$} \\
\hline & Coefficient & s.e. & Coefficient & s.e. & & Coefficient & s.e. & Coefficient & s.e. & \\
\hline Constant & 1.270 & $0.239 * * *$ & 2.558 & $0.196 * * *$ & & 0.009 & 0.228 & 1.814 & $0.195 * * *$ & \\
\hline SFCPART & 0.286 & $0.063 * * *$ & 0.317 & $0.083 * * *$ & & 0.311 & $0.060 * * *$ & 0.256 & $0.082 * * *$ & \\
\hline AGE & 0.025 & $0.005 * * *$ & -0.019 & $0.005 * * *$ & $* * *$ & 0.015 & $0.004 * * *$ & -0.013 & $0.005 * * *$ & $* * *$ \\
\hline MIDCAR & -0.136 & 0.091 & -0.070 & 0.068 & & -0.016 & 0.086 & -0.066 & 0.068 & \\
\hline MALE & 0.279 & $0.089 * * *$ & 0.270 & $0.075 * * *$ & & 0.425 & $0.089 * * *$ & 0.225 & $0.075 * * *$ & $* *$ \\
\hline HIGHEDU & 0.014 & 0.072 & 0.089 & 0.076 & & -0.010 & 0.068 & 0.106 & 0.075 & \\
\hline NORANK & -0.417 & $0.073 * * *$ & -0.547 & $0.090 * * *$ & & -0.648 & $0.068 * * *$ & -0.585 & $0.089 * * *$ & * \\
\hline ULBOT & 0.063 & 0.069 & 0.446 & 0.422 & & 0.077 & 0.065 & 0.620 & 0.419 & \\
\hline TECH & 0.155 & $0.085 *$ & -0.166 & $0.074 * *$ & $* * *$ & -0.081 & 0.080 & -0.163 & $0.074 * *$ & \\
\hline STAFF & 0.341 & $0.102 * * *$ & -0.033 & 0.145 & ** & 0.128 & 0.097 & 0.269 & $0.144 *$ & \\
\hline SALES & 0.438 & $0.111 * * *$ & -0.098 & 0.328 & * & -0.165 & 0.104 & 0.285 & 0.340 & \\
\hline UNION & -0.079 & 0.105 & -0.086 & 0.074 & & -0.080 & 0.100 & -0.232 & $0.074 * * *$ & \\
\hline $\begin{array}{l}\text { Sample size } \\
\text { Log of the } \\
\text { Likelihood }\end{array}$ & & 1392 & & 1142 & & & 1389 & & 1134 & \\
\hline Function & & 334.247 & & 05.901 & & & 655.715 & & 229.999 & \\
\hline Model $\chi^{2}$ & & 178.695 & & 99.322 & & & 269.902 & & 27.405 & \\
\hline
\end{tabular}

Sources: Japanese Worker Representation and Participation Survey (JWRPS)

and Korean Worker Representation and Participation Survey (KWRPS)

Notes:

The statistical significance of the difference in the estimated coefficients between Japan and Korea is tested by pooling the Japanese and Korean samples and estimating a benchmark model

augmented by a full set of interation terms involving between each explanatory variable

and Korea dummy (=1 if the ith employee works for a Korean firm, 0 otherwise).

*Significant at the 10 percent level; **Significant at the 5 percent level; ***Significant at the 1 percent level 
Table 8-2 Ordered Probit Estimates on the Effect on Voice of SFCPART

\begin{tabular}{|c|c|c|c|c|c|c|c|c|c|c|}
\hline \multirow[b]{3}{*}{ Variable } & \multicolumn{5}{|c|}{ Voice on Schedule } & \multicolumn{5}{|c|}{ Voice on Training } \\
\hline & \multicolumn{2}{|r|}{ Japan } & \multicolumn{2}{|r|}{ Korea } & \multirow{2}{*}{$\begin{array}{l}\text { Japan vs. } \\
\text { Korea }\end{array}$} & \multicolumn{2}{|r|}{ Japan } & \multicolumn{2}{|r|}{ Korea } & \multirow{2}{*}{\begin{tabular}{|l} 
Japan vs \\
Korea \\
\end{tabular}} \\
\hline & Coefficient & s.e. & Coefficient & s.e. & & Coefficient & s.e. & Coefficient & s.e. & \\
\hline Constant & 0.540 & $0.225 * *$ & 1.525 & $0.191 * * *$ & & 0.136 & 0.226 & 2.069 & $0.199 * * *$ & \\
\hline SFCPART & 0.258 & $0.059 * * *$ & 0.156 & $0.082 *$ & * & 0.277 & $0.059 * * *$ & 0.224 & $0.083 * * *$ & \\
\hline AGE & -0.008 & $0.004 *$ & -0.003 & 0.005 & & 0.012 & $0.004 * * *$ & -0.015 & $0.005 * * *$ & $* * *$ \\
\hline MIDCAR & 0.058 & 0.086 & -0.057 & 0.068 & & -0.021 & 0.086 & -0.006 & 0.069 & \\
\hline MALE & 0.194 & $0.087 * *$ & 0.033 & 0.074 & * & 0.361 & $0.089 * * *$ & 0.013 & 0.076 & $* * *$ \\
\hline HIGHEDU & 0.075 & 0.067 & 0.184 & $0.075 * *$ & & -0.004 & 0.068 & 0.137 & $0.076 *$ & \\
\hline NORANK & -0.339 & $0.068 * * *$ & -0.508 & $0.089 * * *$ & & -0.599 & $0.068 * * *$ & -0.652 & $0.091 * * *$ & \\
\hline ULBOT & 0.065 & 0.065 & 0.078 & 0.415 & & -0.013 & 0.065 & 0.506 & 0.424 & \\
\hline TECH & -0.060 & 0.080 & -0.192 & $0.073 * * *$ & & -0.117 & 0.080 & -0.098 & 0.075 & \\
\hline STAFF & 0.083 & 0.096 & 0.043 & 0.143 & & 0.128 & 0.097 & 0.224 & 0.146 & \\
\hline SALES & 0.021 & 0.102 & -0.103 & 0.341 & & 0.143 & 0.102 & -0.268 & 0.329 & \\
\hline UNION & 0.133 & 0.099 & -0.052 & 0.073 & & -0.061 & 0.098 & -0.193 & $0.075 * * *$ & \\
\hline $\begin{array}{l}\text { Sample size } \\
\text { Log of the } \\
\text { Likelihood }\end{array}$ & & 1387 & & 1135 & & & 1388 & & 1139 & \\
\hline Function & & -1860.593 & & -1291.804 & & & -1690.282 & & -1139.991 & \\
\hline Model $\chi^{2}$ & & 68.687 & & 70.509 & & & 218.824 & & 110.402 & \\
\hline
\end{tabular}

Sources: Japanese Worker Representation and Participation Survey (JWRPS)

and Korean Worker Representation and Participation Survey (KWRPS)

Notes:

The statistical significance of the difference in the estimated coefficients between Japan and Korea is tested by pooling the Japanese and Korean samples and estimating a benchmark model

augmented by a full set of interation terms involving between each explanatory variable

and Korea dummy (=1 if the ith employee works for a Korean firm, 0 otherwise).

*Significant at the 10 percent level; **Significant at the 5 percent level; ***Significant at the 1 percent level 
Table 9-1 Ordered Probit Estimates on the Effect on Voice of SGAPART

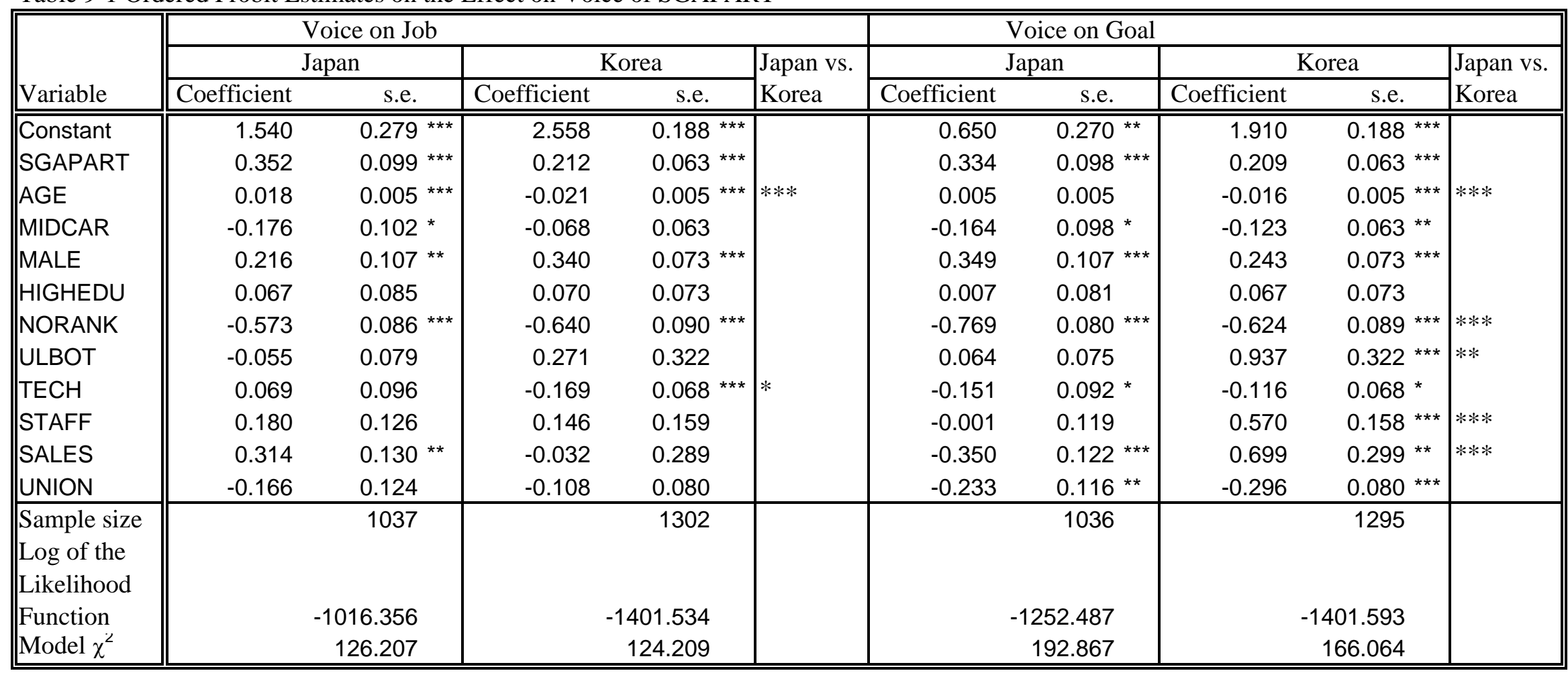

Sources: Japanese Worker Representation and Participation Survey (JWRPS)

and Korean Worker Representation and Participation Survey (KWRPS)

Notes:

The statistical significance of the difference in the estimated coefficients between Japan and Korea is tested by pooling the Japanese and Korean samples and estimating a benchmark model

augmented by a full set of interation terms involving between each explanatory variable

and Korea dummy (=1 if the ith employee works for a Korean firm, 0 otherwise).

*Significant at the 10 percent level; **Significant at the 5 percent level; ***Significant at the 1 percent level 
Table 9-2 Ordered Probit Estimates on the Effect on Voice of SGAPART

\begin{tabular}{|c|c|c|c|c|c|c|c|c|c|c|}
\hline \multirow[b]{3}{*}{ Variable } & \multicolumn{5}{|c|}{ "Voice on Schedule } & \multicolumn{5}{|c|}{ Voice on Training } \\
\hline & \multicolumn{2}{|c|}{ Japan } & \multicolumn{2}{|c|}{ Korea } & \multirow{2}{*}{$\begin{array}{l}\text { Japan vs. } \\
\text { Korea }\end{array}$} & \multicolumn{2}{|c|}{ Japan } & \multicolumn{2}{|c|}{ Korea } & \multirow{2}{*}{\begin{tabular}{|l} 
Japan vs \\
Korea
\end{tabular}} \\
\hline & Coefficient & S.e. & Coefficient & s.e. & & Coefficient & s.e. & Coefficient & s.e. & \\
\hline Constant & 0.741 & $0.265 * \star \star$ & 1.694 & 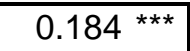 & & 0.413 & 0.269 & 2.122 & $0.190 * \star \star$ & \\
\hline AGE & -0.012 & 0.005 ** & -0.009 & 0.005 * & & 0.008 & 0.005 * & -0.015 & $0.005 * * \star$ & $* * *$ \\
\hline MIDCAR & 0.103 & 0.097 & -0.131 & $0.062 * *$ & $* *$ & -0.102 & 0.097 & -0.096 & 0.064 & \\
\hline MALE & 0.241 & $0.106 * *$ & 0.068 & 0.072 & * & 0.215 & $0.107 * *$ & 0.034 & 0.074 & * \\
\hline ULBOT & 0.045 & 0.075 & 0.431 & 0.319 & & 0.056 & 0.076 & 0.760 & $0.310 * \star \star$ & * \\
\hline TECH & -0.031 & 0.091 & -0.095 & 0.067 & & -0.132 & 0.092 & -0.108 & 0.069 & \\
\hline STAFF & 0.069 & 0.119 & 0.330 & $0.157 * *$ & & 0.095 & 0.120 & 0.266 & 0.159 * & \\
\hline SALES & -0.083 & 0.120 & 0.455 & 0.297 & & 0.016 & 0.120 & -0.132 & 0.295 & \\
\hline UNION & 0.134 & 0.116 & -0.151 & 0.079 * & $* *$ & -0.189 & 0.116 * & -0.159 & 0.081 ** & \\
\hline Model $\chi^{<}$ & & 81.107 & & 115.084 & & & 69.599 & & 123.197 & \\
\hline
\end{tabular}

Sources: Japanese Worker Representation and Participation Survey (JWRPS)

and Korean Worker Representation and Participation Survey (KWRPS)

Notes:

The statistical significance of the difference in the estimated coefficients between Japan and Korea is tested by pooling the Japanese and Korean samples and estimating a benchmark model

augmented by a full set of interation terms involving between each explanatory variable

and Korea dummy (=1 if the ith employee works for a Korean firm, 0 otherwise).

*Significant at the 10 percent level; **Significant at the 5 percent level; ***Significant at the 1 percent level 
Table 10-1 Ordered Probit Estimates on the Effect on Demand for Voice of PSP

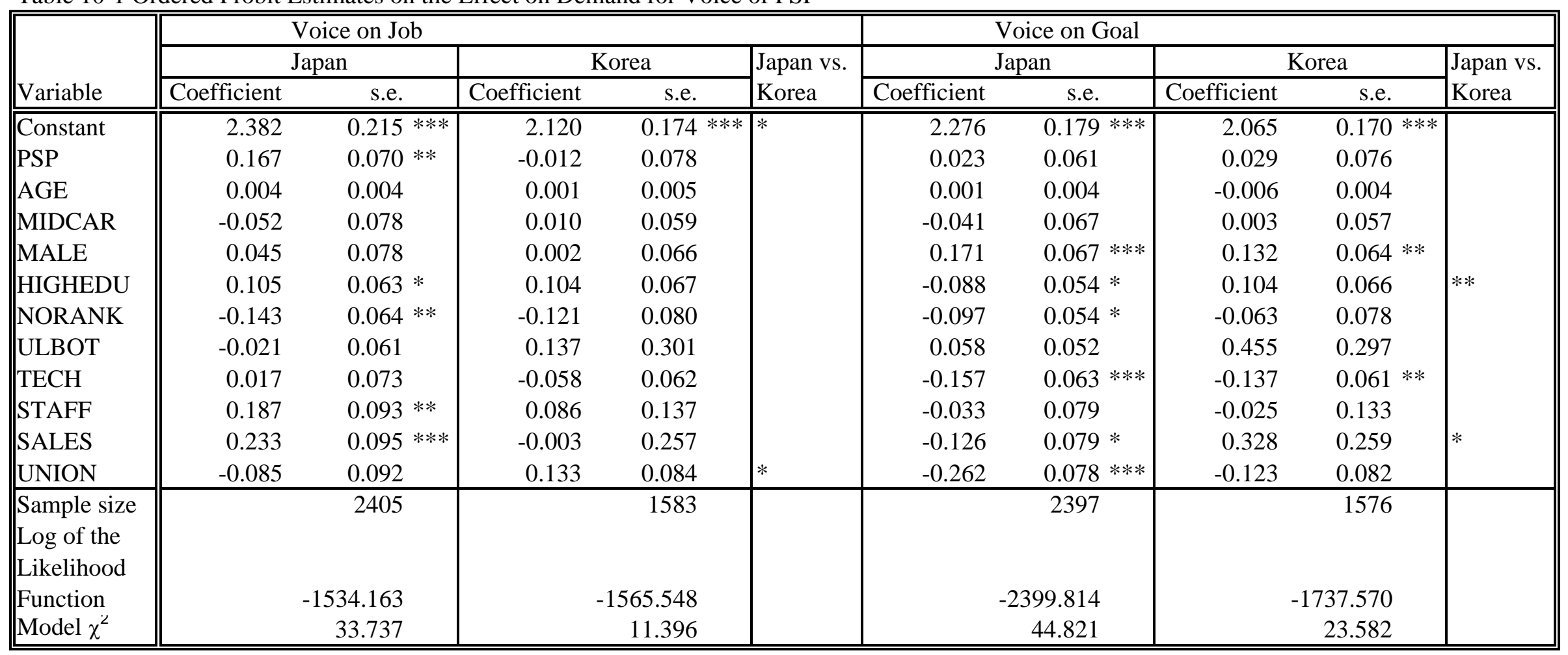

Sources: Japanese Worker Representation and Participation Survey (JWRPS)

and Korean Worker Representation and Participation Survey (KWRPS)

Notes:

The statistical significance of the difference in the estimated coefficients between Japan and Korea is tested by pooling the Japanese and Korean samples and estimating a benchmark model

augmented by a full set of interation terms involving between each explanatory variable

and Korea dummy (=1 if the ith employee works for a Korean firm, 0 otherwise).

*Significant at the 10 percent level; **Significant at the 5 percent level; ***Significant at the 1 percent level 
Table 10-2 Ordered Probit Estimates on the Effect on Demand for Voice of PSP

\begin{tabular}{|c|c|c|c|c|c|c|c|c|c|c|}
\hline \multirow[b]{3}{*}{ Variable } & \multicolumn{5}{|c|}{ Voice on Schedule } & \multicolumn{5}{|c|}{ "Voice on Training } \\
\hline & \multicolumn{2}{|r|}{ Japan } & \multicolumn{2}{|r|}{ Korea } & \multirow{2}{*}{$\begin{array}{l}\text { Japan vs. } \\
\text { Korea }\end{array}$} & \multicolumn{2}{|r|}{ Japan } & \multicolumn{2}{|r|}{ Korea } & \multirow{2}{*}{\begin{tabular}{|l} 
Japan vs \\
Korea \\
\end{tabular}} \\
\hline & Coefficient & s.e. & Coefficient & s.e. & & Coefficient & s.e. & Coefficient & s.e. & \\
\hline Constant & 2.481 & $0.174 * * *$ & 2.291 & $0.171 * * *$ & & 1.783 & $0.181 * * *$ & 2.296 & $0.171 * * *$ & \\
\hline PSP & 0.040 & 0.059 & -0.020 & 0.076 & & 0.211 & $0.061 * * *$ & -0.100 & 0.076 & $* * *$ \\
\hline AGE & -0.007 & $0.003 * *$ & -0.012 & $0.004 * * *$ & & 0.008 & $0.004 * *$ & -0.010 & $0.004 * *$ & $* * *$ \\
\hline MIDCAR & -0.069 & 0.065 & 0.011 & 0.058 & & -0.101 & 0.068 & -0.020 & 0.058 & \\
\hline MALE & -0.150 & $0.066 * *$ & -0.043 & 0.064 & & 0.213 & $0.067 * * *$ & 0.097 & 0.064 & \\
\hline HIGHEDU & 0.000 & 0.052 & 0.044 & 0.066 & & 0.048 & 0.054 & 0.050 & 0.066 & \\
\hline NORANK & -0.115 & $0.052 * *$ & -0.069 & 0.078 & & -0.217 & $0.055 * * *$ & -0.140 & $0.078 *$ & $* *$ \\
\hline ULBOT & -0.030 & 0.051 & 0.263 & 0.292 & & -0.040 & 0.053 & 0.657 & $0.303 * *$ & \\
\hline TECH & -0.126 & $0.062 * *$ & -0.099 & $0.061 *$ & & -0.130 & $0.064 * *$ & -0.054 & 0.061 & \\
\hline STAFF & -0.061 & 0.076 & -0.033 & 0.133 & & -0.086 & 0.079 & 0.211 & 0.134 & * \\
\hline SALES & -0.174 & $0.077 * *$ & 0.122 & 0.254 & & 0.072 & 0.081 & 0.049 & 0.253 & \\
\hline UNION & -0.023 & 0.075 & 0.024 & 0.082 & & -0.208 & $0.079 * * *$ & 0.114 & 0.083 & $* * *$ \\
\hline $\begin{array}{l}\text { Sample size } \\
\text { Log of the } \\
\text { Likelihood }\end{array}$ & & 2399 & & 1576 & & & 2399 & & 1579 & \\
\hline Function & & -2700.611 & & -1697.681 & & & -2405.268 & & -1679.804 & \\
\hline Model $\chi^{2}$ & & 21.362 & & 15.546 & & & 86.293 & & 23.103 & \\
\hline
\end{tabular}

Sources: Japanese Worker Representation and Participation Survey (JWRPS)

and Korean Worker Representation and Participation Survey (KWRPS)

Notes:

The statistical significance of the difference in the estimated coefficients between Japan and Korea is tested by pooling the Japanese and Korean samples and estimating a benchmark model

augmented by a full set of interation terms involving between each explanatory variable

and Korea dummy (=1 if the ith employee works for a Korean firm, 0 otherwise).

*Significant at the 10 percent level; **Significant at the 5 percent level; ***Significant at the 1 percent level 
Table 11 Ordered Probit Estimates on the Effect on Employee Suggestion of SFC, SGA, JLMC, and PSP

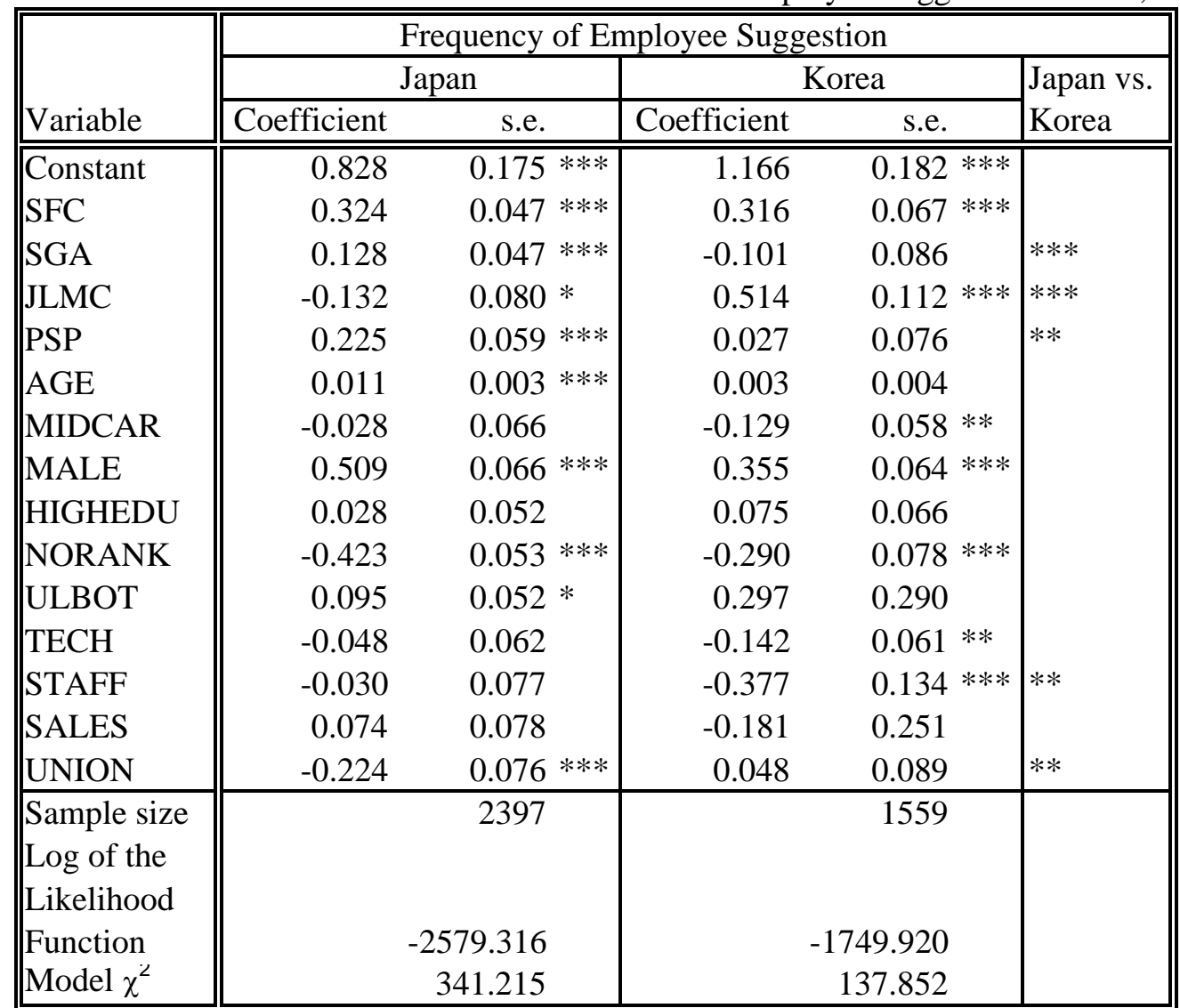

Sources: Japanese Worker Representation and Participation Survey (JWRPS) and Korean Worker Representation and Participation Survey (KWRPS)

Notes:

The statistical significance of the difference in the estimated coefficients between Japan and Korea is tested by pooling the Japanese and Korean samples and estimating a benchmark model augmented by a full set of interation terms involving between each explanatory variable and Korea dummy ( $=1$ if the ith employee works for a Korean firm, 0 otherwise).

*Significant at the 10 percent level; **Significant at the 5 percent level; ***Significant at the 1 percent level 